\title{
Protective Effect of Sika Deer (Cervus nippon) Velvet Antler Extract against Cisplatin-Induced Kidney and Liver Injury in a Prostate Cancer PC-3 Cell Xenograft Model
}

\author{
Yujiao Tang, ${ }^{1,2}$ Meiqi Fan, ${ }^{2}$ Young-Jin Choi, ${ }^{2}$ Eun-Ju Choi, ${ }^{3}$ Sang-Ho Moon, ${ }^{2}$ \\ Trishna Debnath, ${ }^{4}$ Yonghai Yu, ${ }^{1}$ Il Nam Lee, ${ }^{5}$ and Eun-Kyung Kim $\left(^{2}\right.$ \\ ${ }^{1}$ School of Bio-science and Food Engineering, Changchun University of Science and Technology, Changchun 130-600, China \\ ${ }^{2}$ Division of Food Bioscience, College of Biomedical and Health Sciences, Konkuk University, Chungju 27478, Republic of Korea \\ ${ }^{3}$ Department of Physical Education, College of Education, Daegu Catholic University, Gyeongsan 38430, Republic of Korea \\ ${ }^{4}$ Department of Food Science and Biotechnology, Dongguk University, Goyang 10326, Republic of Korea \\ ${ }^{5}$ R\&D Department, Korea Mcnulty Co., Ltd., Cheonan 31009, Republic of Korea
}

Correspondence should be addressed to Eun-Kyung Kim; eunkyungkim@kku.ac.kr

Received 1 February 2018; Revised 27 July 2018; Accepted 3 October 2018; Published 11 November 2018

Guest Editor: Mariusz Korczyński

Copyright (c) 2018 Yujiao Tang et al. This is an open access article distributed under the Creative Commons Attribution License, which permits unrestricted use, distribution, and reproduction in any medium, provided the original work is properly cited.

We previously discovered the antioxidant and antiprostate cancer effects of antler extract (AE), but whether it inhibits cisplatin(Cis-) induced toxicity has not been investigated. In this study, the effect of AE on Cis-induced side effects in the kidney and liver using 3-(4,5-dimethyl-2-thiazolyl)-2,5-diphenyl-2H-tetrazolium bromide-based cytotoxicity and cell cycle assays in prostate cancer PC-3 cells in vitro is investigated. Furthermore, we used a xenograft mouse model of the same cells to examine the in vivo effects and mechanisms of action. Cis and Cis + AE treatment attenuated prostate cancer cell growth by inducing apoptosis in vitro. Cis $+\mathrm{AE}$ stimulated cleaved caspases 3, 7, and 9 and polyadenosine diphosphate ribose polymerase expression. Cis $+\mathrm{AE}$ treatment for 1 week significantly increased the superoxide dismutase and catalase antioxidant activity while thiobarbituric acid reactive substances decreased. The histopathological damage and tumor necrosis factor- $\alpha$, interleukin- (IL-) $1 \beta$ and IL-6, cyclooxygenase-2, and inducible nitric oxide synthase expression in the kidney and liver tissue decreased. Therefore, AE likely possesses antiprostate cancer activity and inhibits Cis toxicity.

\section{Introduction}

Prostate cancer (PC) is one of the most common malignancies and represents the second most common cause of cancer-associated mortalities among men in the US [1]. PC is divided into two types: hormone-dependent and hormone-independent. Hormonal therapy remains the most effective therapy for patients with advanced PC by inhibiting proliferation and inducing apoptosis of tumor cells (hormone-dependent) [2]. However, after short-term remissions (18-24 months), the growth of surviving tumor cells recurs with castrate-resistant prostate cancer (CRPC) with inevitable progression and death within 2 to 3 years in most men (hormone-independent) $[3,4]$.
Cisplatin (Cis) is a widely used anticancer drug and one of the most potent antitumor drugs used against a wide spectrum of malignancies including PC, testicular, bladder, head and neck, ovarian, breast, and lung cancer [5-10]. Indeed, it is used to treat $50 \%$ of all cancers [11]. Cis, a neutral inorganic and square planar complex, acts by binding with DNA to form adducts leading to unique cellular responses that mainly culminate in apoptosis induction [12]. Despite its use as a chemotherapeutic agent, Cis exerts serious side effects in several organs including the kidneys and liver $[13,14]$ mainly due to its high accumulation in these organs $[14,15]$. There is evidence implicating oxidative stress in the pathogenesis of Cis-induced kidney and liver injury, mediated by 
increased reactive oxygen species [16-19]. Therefore, there is an urgent need to discover a novel, less toxic substance without potent antitumor activity.

Velvet antler, the unossified antler of Cervus elaphus, is well known as an animal-based folk medicine widely used in Asia as an alternative oriental medicine to treat various diseases including osteoarthritis, myocardial infarction, hypertension, breast cancer, and PC [20-24]. Our previous research showed that antler extract (AE) exhibited antioxidant and antiprostate cancer activity $[24,25]$. However, the inhibitory effect of AE on Cis-induced toxicity has not been investigated, and therefore, the present study investigated this phenomenon for the first time.

\section{Materials and Methods}

2.1. Materials. Cis, protease inhibitor cocktail, radioimmunoprecipitation assay (RIPA) buffer, 2-propanol, 3-(4,5dimethyl-2-thiazolyl)-2,5-diphenyl-2H-tetrazolium bromide (MTT), dimethyl sulfoxide (DMSO), chloroform, and propidium iodide were purchased from Sigma-Aldrich Chemicals (St. Louis, MO, USA). Cycle script reverse transcription (RT) premix (dT20), RT/polymerase chain reaction (PCR) premix, and the $100 \mathrm{bp}$ DNA Ladder were obtained from BIONEER (Daejeon, Korea). Trizol reagent, diethyl pyrocarbonate- (DEPC-) treated water, bicinchoninic acid (BCA) protein assay reagents $\mathrm{A}$ and $\mathrm{B}$, Ponceau $\mathrm{S}$, and the lane marker sample buffers were purchased from Thermo Scientific (Waltham, MA, USA). RNase A and Tween-20 were supplied by Novagen (Darmstadt, Germany). The PC-3 human prostate cancer cell line was obtained from the Korean Cell Line Bank (Seoul, Korea, KCLB number: 21435). The Roswell Park Memorial Institute (RPMI) 1640 medium, fetal bovine serum (FBS), penicillin/streptomycin (P/S), 0.5\% trypsinethylenediaminetetraacetic acid (EDTA), and phosphatebuffered saline (PBS) for the cells culture were from Invitrogen (Carlsbad, CA, USA).

2.2. Preparation of Extracts. The antler sample was extracted according to a previously reported method [25]. In brief, the antlers were harvested at approximately growing day 50 and then were divided into three segments: top, middle, and base. In this study, we used the top segments, which were lyophilized and homogenized with a grinder, and then, $100 \mathrm{~g}$ was extracted with $1000 \mathrm{~mL}$ boiling distilled water (DW) for $1 \mathrm{~h}$. The AE was subsequently filtered $(0.25 \mu \mathrm{m}$ pore size $)$ and then lyophilized using a freeze dryer for 5 days.

2.3. Cell Culture. The PC-3 cells were cultured in the RPMI 1640 medium supplemented with $10 \%$ FBS and $1 \% \mathrm{P} / \mathrm{S}$ exposed to a $5 \% \mathrm{CO}_{2}$ atmosphere at $37^{\circ} \mathrm{C}$. For the migration assay, the cells were seeded at a density of $5.0 \times 10^{5}$ cells/well in a six-well culture plate, incubated for $24 \mathrm{~h}$, treated with $125-1,000 \mu \mathrm{g} / \mathrm{mL}$ of $\mathrm{AE}$ for $24 \mathrm{~h}$, and then harvested for analysis.
2.3.1. Cytotoxic Assessment Using MTT Assay. The cell cytotoxicity was determined using the MTT assay. The assay is based on the principle that the yellow tetrazolium salt is metabolized by viable cells to purple formazan crystals in a reaction catalyzed by mitochondrial succinyl dehydrogenase.

In brief, PC- 3 cells were seeded at $1.9 \times 10^{4}$ cells/well in 96-well microtiter plates in the complete medium (RPMI with $10 \% \mathrm{FBS}$ and $1 \% \mathrm{P} / \mathrm{S}$ ) and incubated for $24 \mathrm{~h}$ exposed to a $5 \% \mathrm{CO}_{2}$ atmosphere at $37^{\circ} \mathrm{C}$. Then, $200 \mu \mathrm{L}$ samples of the solution in the medium were transferred to the wells, followed by a $24 \mathrm{~h}$ incubation, and then, the MTT solution (final concentration, $0.5 \mathrm{mg} / \mathrm{mL}$ ) was added to each well. After a $4 \mathrm{~h}$ incubation, the medium was aspirated, the purple crystals were dissolved in DMSO, and the absorbance of the resulting solution in each well was measured at $540 \mathrm{~nm}$ using a microplate reader.

2.3.2. Cell Cycle. For the cell cycle analysis, the harvested cells were fixed with ethanol (with $0.5 \%$ Tween-20) for $8-$ $24 \mathrm{~h}$, washing with $1 \times \mathrm{PBS}$, incubated with $50 \mu \mathrm{g} / \mathrm{mL}$ propidium iodide and $1 \mu \mathrm{g} / \mathrm{mL}$ RNase $\mathrm{A}$ at $37^{\circ} \mathrm{C}$ for $30 \mathrm{~min}$, and then analyzed using flow cytometry using the fluorescenceactivated cell sorting (FACS) system (BD, Franklin Lakes, NJ, USA). The cells of the sub-G1 population were considered apoptotic, and the percentage of each cell cycle phase was determined.

2.4. Animal Experiments. The nude male BALB/c mice (15-17 g and 8-week-old) used in the present study were provided by Samtako Bio Co, (Osan, Korea). They were maintained in an air-conditioned room $\left(20-25^{\circ} \mathrm{C}\right)$ under a $12 \mathrm{~h} \mathrm{light/dark} \mathrm{cycle} \mathrm{with} \mathrm{free} \mathrm{access} \mathrm{to} \mathrm{food} \mathrm{and} \mathrm{water.} \mathrm{The}$ mice were acclimatized to the new environment for 1 week before the commencement of the experiment (Figure 1). The mice were inoculated subcutaneously with $6.5 \times 10^{5}$ PC-3 cells suspended in $100 \mu \mathrm{L}$ PBS thrice weekly. When the xenograft tumors reached a volume of approximately $100 \mathrm{~mm}^{3}$, the mice were randomly assigned to four groups $(n$ = 6/group) and were treated as follows. Group 1 (sham control) was administered PBS, Group 2 received $20 \mathrm{mg} / \mathrm{kg}$ body weight Cis, and Groups 3 and 4 each received $20 \mathrm{mg} / \mathrm{kg}$ body weight Cis, followed by 200 and $400 \mathrm{mg} / \mathrm{kg}$ body weight $\mathrm{AE}(\mathrm{AE}$ low dose (AEL) and high dose $(\mathrm{AEH}))$. The doses of Cis and the extract concentrations were selected based on previous studies [26-30]. At the end of the treatment, the gavage tube was left in place for several seconds to avoid regurgitation and ensure the total calculated dose was administered. The tumor sizes were monitored every 2 days using a digital caliper, and the tumor volumes were calculated using the formula: $L \times S^{2} \times 0.5$, where $L$ and $S$ represent the longest and shortest tumor diameters, respectively [31]. The mice were also weighed. The extract was administered once daily at a fixed time for the entire 2-week experiment. At the end of the experiment, all the mice were fasted overnight, and the xenograft tumors were rapidly excised and weighed. One part of each excised tumor was immediately placed in liquid nitrogen for western 


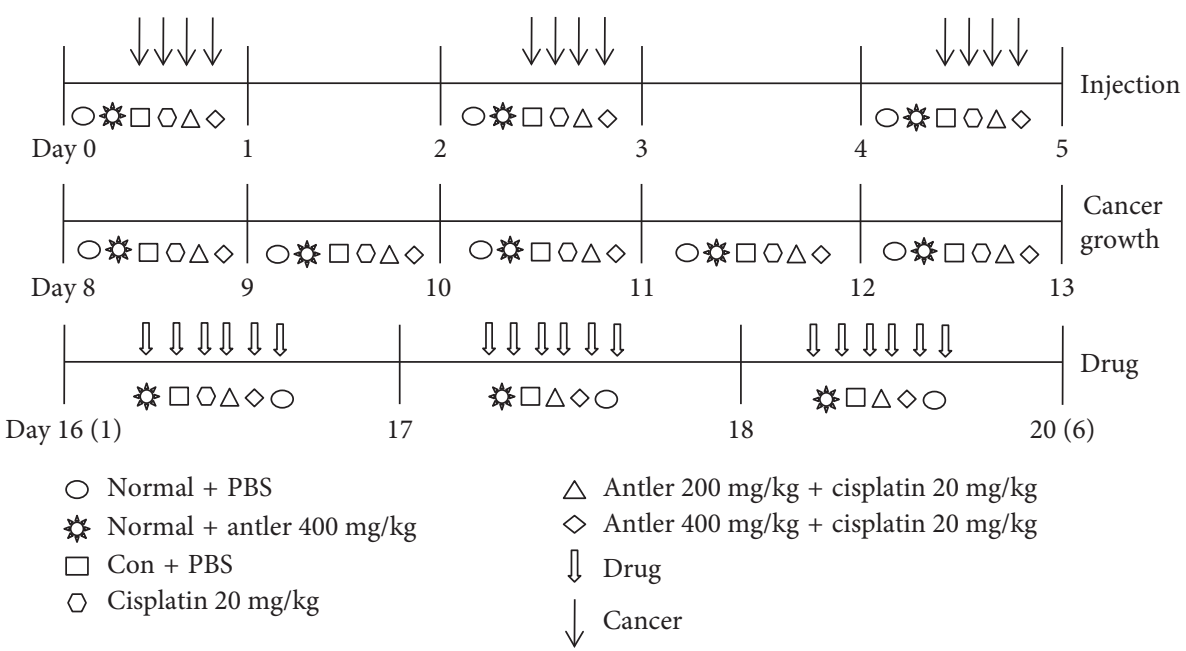

Figure 1: Scheme of the xenograft tumor model. Negative control (NC, phosphate-buffered saline (PBS), $200 \mu \mathrm{L}$ ), antler extract (AE $400 \mathrm{mg} / \mathrm{kg}$ ), control (Con, PBS $200 \mu \mathrm{L}+$ tumor cells), cisplatin (Cis $20 \mathrm{mg} / \mathrm{kg}+$ tumor cells), Cis + AE low dose (AEL, $200 \mathrm{mg} / \mathrm{kg}+\mathrm{Cis}$ $20 \mathrm{mg} / \mathrm{kg}+$ tumor cells), and Cis + AE high dose (AEH, $400 \mathrm{mg} / \mathrm{kg}+$ Cis $20 \mathrm{mg} / \mathrm{kg}+$ tumor cells). From day 0 , mice were injected thrice weekly, and CON, Cis, AEL, and AEH groups were left for 1 week. When the xenograft tumor volumes were approximately $100 \mathrm{~mm}^{3}$, mice were randomly assigned to four groups and treated accordingly.

blot analysis, while the other was fixed in $10 \%$ neutralbuffered formalin for immunohistochemical analysis. Blood samples were collected from the heart. All animal care procedures and experiments were approved by the Institutional Animal Care and Use Committee of Konkuk University (KU15114).

2.5. RNA Isolation and $m R N A$ Expression Analysis. RNA was isolated from the cells using Trizol according to the manufacturer's protocol. The first-strand complementary DNA (cDNA) was synthesized using Superscript II reverse transcriptase (Invitrogen). The PCR was performed as previously described, except for the following primer set: tumor necrosis factor- (TNF-) a (sense, 5'-ACC AGG AGA GAA AGT CAA CCT C-3', and antisense, 5'-GGA CTC CGC AAA GTC TAA GT- $3^{\prime}$ ), interleukin- (IL-) $1 \beta$ (sense, $5^{\prime}$ TCT GTG ACT CAT GGG ATG AT-3', and antisense, $5^{\prime}$ TAT TTT TGT CGT TGC TTG GTT-3') and IL-6 (sense, $5^{\prime}$ GAG ACT TCC ATC CAG TTG C-3', and antisense, $5^{\prime}$ CTC TTT TCT CAT TTC CAC GA-3'), cyclooxygenase(COX-) 2 (sense, $5^{\prime}$-CCC CTC TCT ACG CAT TCT AT-3', and antisense, $5^{\prime}$-AGG TCG TTT GTT GGG ATT AT-3'), inducible nitric oxide synthase (iNOS) (sense, $5^{\prime}$ - ATC ATG AAC CCC AAG AGT TT-3', and antisense, 5'-AGA GTG AGC TGG TAG GTT CC-3'), and glyceraldehyde 3-phosphate dehydrogenase (GAPDH, sense, 5'-GGT TGT CTC CTG CGA CTT CA-3', and antisense, 5' - TAG GGC CTC TCT TGC TCA GT- $3^{\prime}$ ), which was used as the internal control.

2.5. Western Blotting. The cell extracts were prepared using the detergent lysis procedure as described elsewhere [24]. Protein samples $(40 \mu \mathrm{g})$ were electrophoresed using Novex $4 \%-12 \%$ Bis-Tris gels (Life Technologies, Carlsbad, CA, USA) and then transferred to nitrocellulose membranes for
7 min using the iBlot dry blotting system (Life Technologies). The membranes were blocked overnight at $4^{\circ} \mathrm{C}$ with clear milk (Thermo Scientific, IL, USA) and then subsequently incubated with primary antibodies $(1: 2000$ in $1 \times$ Tris-buffered saline plus Tween (TBST) for $1 \mathrm{~h}$. Antibodies against Cox-2, iNOS, and actin were purchased from Santa Cruz Biotechnology. Polyadenosine diphosphate (ADP) ribose polymerase (cleaved PARP; caspases 3, 7, and 9; cleaved caspases 3, 7, and 9; and B-cell lymphoma-2 (Bcl2)) and $\mathrm{Bcl}-2$-associated $X$ protein (Bax) antibodies were from Cell Signaling Technology (Danvers, MA, USA). The goat anti-rabbit and goat anti-mouse horseradish peroxidase-conjugated secondary antibodies (Santa Cruz Biotechnology, Dallas, TX, USA) were used ( $1: 2000$, in $1 \times$ TBST). Equal protein loading was ascertained using Ponceau S staining of the blotted membranes and western blotting with $\beta$-actin bodies. Immunodetection was performed using an enhanced chemiluminescence detection kit (Amersham Pharmacia, Piscataway, NJ, USA). Goat anti-rabbit and goat anti-mouse horseradish peroxidaseconjugated secondary antibodies (Santa Cruz Biotechnology, Dallas, TX, USA) were used $(1: 2000$, in $1 \times$ TBST).

2.5. Serum Biochemical Parameters. Serum was obtained by centrifuging the blood samples at $3,500 \mathrm{~g}$ for $15 \mathrm{~min}$ at $4^{\circ} \mathrm{C}$. The superoxide dismutase (SOD), catalase (CAT), and thiobarbituric acid reactive substances (TBARS) assays were performed using a kit (Cayman Chemical Co., MI, USA).

2.6. Histological Analysis. The kidneys and livers of the mice were fixed with $10 \%$ paraformaldehyde and embedded in paraffin blocks, which were then cut into $5 \mu \mathrm{m}$ thick sections, deparaffinized, and stained with hematoxylin and eosin (H\&E). 
2.7. Statistical Analysis. The data are presented as the mean \pm standard error (SE) of triplicate experiments. The statistical analyses were performed using the statistical analysis software (SAS) program (SAS Institute, USA). The treatment effects were analyzed using a one-way analysis of variance (ANOVA), followed by Dunnett's multiple range tests. The statistical significance was defined at $p<0.05$.

\section{Results}

3.1. Effect of Cis and AE on Growth and Morphology of PC-3 Cells In Vitro. The effects of Cis and AE on the proliferation of PC-3 cells were investigated. The cell line was cultured in vitro with the same concentration of $\mathrm{Ci}(200 \mu \mathrm{M})$ and different concentrations of AE $(125-1,000 \mu \mathrm{g} / \mathrm{mL})$ for $24 \mathrm{~h}$, and cell viability was measured using the MTT assay. The results demonstrated that the proliferation of PC-3 cells decreased more in the $\mathrm{Cis}$ and $\mathrm{Cis}+\mathrm{AE}$ groups than it did in the control group. Moreover, $\mathrm{Cis}+\mathrm{AE}$ (500 and $1,000 \mu \mathrm{g} / \mathrm{mL}$ ) significantly decreased to Cis (Figure 2(a)). Therefore, Cis + AE 500 and $1,000 \mu \mathrm{g} / \mathrm{mL}$ were selected for the apoptosis study.

The PC-3 cells line used was treated for $24 \mathrm{~h}$. Light microscopy of the Cis-, Cis + AEL-, and Cis + AEHtreated PC-3 cells showed a significant morphological change. As shown in Figure 2(b), the control group cells did not show any apoptotic characteristics. However, Cis and AE treatment dramatically and dose-dependently induced cell morphology changes including shrinkage and detachment. Consistent with the cell viability results, PC- 3 cells cultured with Cis + AEL and Cis + AEH showed more marked morphological changes than cells cultured with $\mathrm{Cis}$ alone, suggesting that $\mathrm{AE}$ may induce more apoptosis.

\subsection{Apoptotic Effects of Cis and AE in PC-3 Cells. Flow} cytometric analysis was used to determine the cell cycle distribution of the PC-3 cells in the absence and presence of Cis and AE for $24 \mathrm{~h}$. As indicated in Figure 3, Cis, Cis + AEL, and $\mathrm{Cis}+\mathrm{AEH}$ showed no significant changes in the percentage of cells in the G1, S, and G2 phases compared with the basal level (control). Specifically, there was a $51.4 \%$, $62.6 \%$, and $69.8 \%$ increase in the G1, S, and G2 apoptosis phases, respectively, compared with that of the control. The results indicated that $\mathrm{Cis}+\mathrm{AEL}$ and $\mathrm{Cis}+\mathrm{AEH}$ induced apoptosis more potently than Cis did.

3.3. Effect of AE on Apoptotic Protein Expression in PC-3 Cells. To determine whether the apoptotic effects of Cis and $\mathrm{AE}$ were mediated by the caspase-dependent apoptosis pathway, the Cis-, Cis + AEL-, and Cis + AEH-treated cells were analyzed using western blotting of intracellular full length and cleaved PARP, caspases 3, 7, and 9, and Bax and Bcl-2 (Figure 4). The results (Figures 4(b)-4(i)) showed that treatment with AEL and AEH decreased the inactive PARP and caspases 7 and 9, but the active cleaved PARP and caspases 3, 7, and 9 significantly increased gradually over the concentrations tested. This observation indicates that AE induced self-cleavage of caspases 3, 7, and 9 and PARP to activate the downstream signaling pathway. Bcl-2 family proteins affect cellular apoptosis by regulating cytochrome $\mathrm{C}$ release, which then mediates caspase activation. Therefore, the effects of Cis, Cis + AEL, and Cis + AEH on the protein expression of antiapoptotic $\mathrm{Bcl}-2$ and proapoptotic Bax were evaluated. In Figures 4(j) and 4(k), treatment with AEL and AEH significantly decreased the protein expression of $\mathrm{Bcl}-2$ and significantly increased that of Bax compared to the Cis group. Taken together, these data suggest that $\mathrm{AE}$ played a role in the induction of apoptosis.

3.4. Effect of AE on Cis-Induced Changes in Food Intake and Body Weight. To analyze the effects of AE and Cis on food intake and body weight, the animals were treated with the vehicle (NC), AEH, Cis + AEL, and Cis + AEH. Administration of $\mathrm{Cis}$ reduced the food intake and body weight, but AE treatment significantly increased the food intake and body weight (Figure 5). In addition, the AEH and control groups exhibited no significant effects on food intake and body weight. Therefore, high-dose AE did not show toxic effects in nude mice and was used for the subsequent experiments.

3.5. Effect of AE on Cis-Induced Alterations of Antioxidants. The effects of Cis and AE on the antioxidant enzymes, SOD and CAT, in mice are shown in Figures 6(a)-6(c). As illustrated in Figures 6(a) and 6(b), exposure to Cis decreased the SOD and CAT activities, but the activities significantly increased in the $\mathrm{Cis}+\mathrm{AE}$ groups. In contrast, the TBARS contents significantly increased in the Cis-treated group but significantly decreased in the Cis $+\mathrm{AE}$ groups (Figure 6(c)). In mice administered with AE only, the SOD and CAT activities were highest, while the TBARS content was the lowest. Therefore, $\mathrm{AE}$ alleviated the changes induced by oxidative stress.

3.6. Effect of Cis and $A E$ on Expression of InflammationRelated Genes in Kidney and Liver. We also investigated the expression of inflammation-related genes in the kidney and liver. Initially, the mRNA expression levels of TNF- $\alpha$, IL- $1 \beta$, IL-6, COX-2, and iNOS in the kidney tissues were estimated. As shown in Figure 7, kidney tissues from $\mathrm{Cis}+\mathrm{AE}$-treated groups showed significantly decreased TNF- $\alpha$, IL- $1 \beta$, COX-2, and iNOS expression compared with that of the Cis-treated group. However, no significant change was observed in the expression of IL- 6 . The results of the liver tissue analysis (Figure 8) were similar to those of the kidney. Specifically, treatment with Cis + AE significantly decreased the kidney tissue expression of TNF- $\alpha$, IL- $1 \beta$, IL-6, COX-2, and iNOS compared with that of the Cis group.

3.7. Effect of Cis and AE on Histology of Kidney and Liver Tissues. As shown in Figure 9(a), the normal group showed normal histology of the mouse kidneys (the glomeruli, 


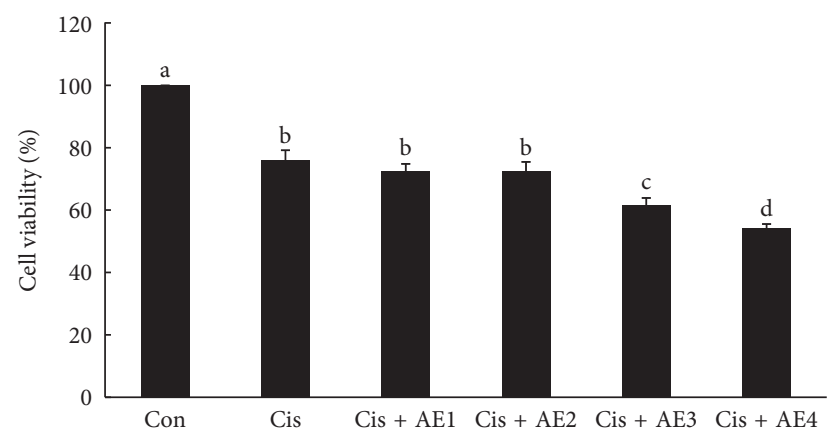

(a)

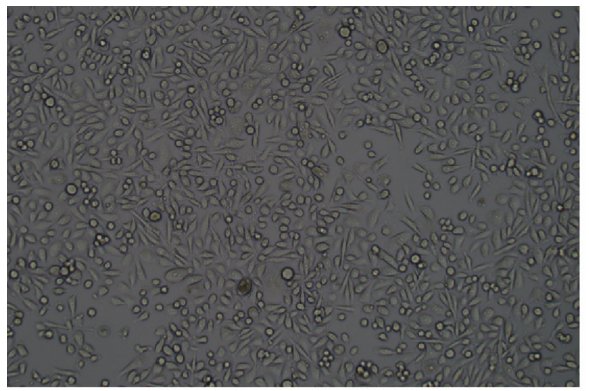

Con

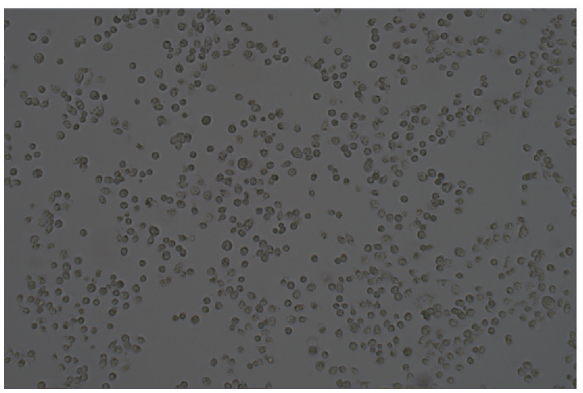

Cis + AE3

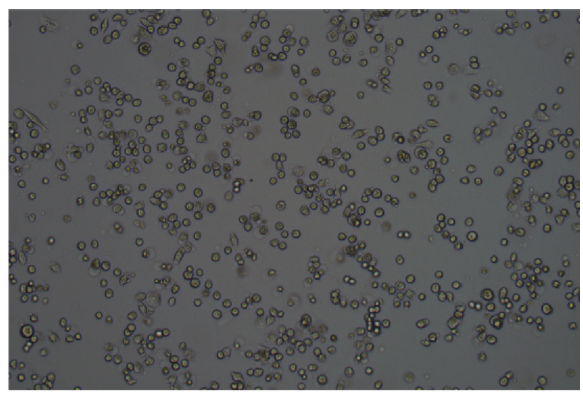

Cis

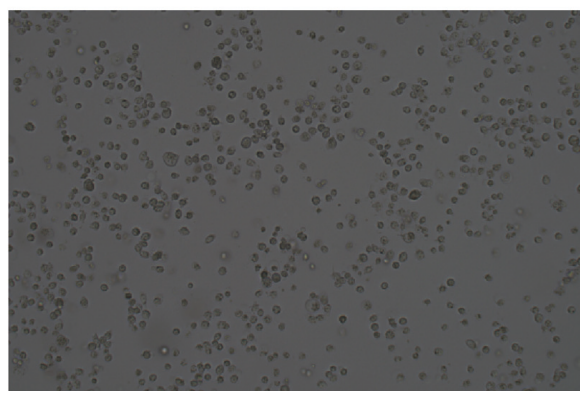

$\mathrm{Cis}+\mathrm{AE} 4$

(b)

Figure 2: Antiproliferative effect of cisplatin (Cis) and Cis plus antler extract (AE, 125-1,000 $\mu \mathrm{g} / \mathrm{mL}$ ) in PC-3 prostate cancer cells. Cis $(200 \mu \mathrm{M})$, Cis $+\mathrm{AE} 1(\mathrm{Cis} 200 \mu \mathrm{M}+\mathrm{AE} 125 \mu \mathrm{g} / \mathrm{mL})$, Cis $+\mathrm{AE} 2$ (Cis $200 \mu \mathrm{M}+\mathrm{AE} 250 \mu \mathrm{g} / \mathrm{mL})$, Cis $+\mathrm{AE} 3(\mathrm{Cis} 200 \mu \mathrm{M}+\mathrm{AE} 500 \mu \mathrm{g} / \mathrm{mL})$, and Cis $+\mathrm{AE} 4($ Cis $200 \mu \mathrm{M}+\mathrm{AE} 1,000 \mu \mathrm{g} / \mathrm{mL}) .{ }^{\mathrm{a}-\mathrm{d}}$ Means with different superscript in the same row are different $(p<0.05)$.

tubules, interstitium, and blood vessels). The Cis group exhibited proteinaceous casts in the tubular lumen. In addition, the Cis group showed inflammation of the blood vessels, increased thickness of Bowman's capsules, and decreased glomerulus size. Cis + AEH treatment improved the kidney histopathology by reducing the inflammation of the blood vessels and the glomerulus size, which was similar to that of the normal group.

The normal microscopic architecture of the liver is composed of hexagonal lobules and acini. Hexagonal lobules are centered on the central vein (CV) and have a portal triad containing branches of the portal vein (PV), hepatic artery (HA), and bile duct (BD). The liver sections from the Cis-treated group exhibited severe congestion of the $\mathrm{CV}$ and moderate disorganization of the hepatic cords (Figure 9(b)). In the Cis + AEH group, the liver sections showed mild congestion of the CV and mild disorganization of hepatic cords.

\section{Discussion}

$\mathrm{AE}$ has several pharmacological properties and has been used in the clinical treatment of numerous diseases [21-24, 32, 33]. Cis has been shown to cause hepatotoxicity, nephrotoxicity, and other side effects, which limit its use [34]. The increased incidence and mortality of PC and the current unsatisfactory treatment options for CRPC has increased the focus on the combination of Cis and natural-based medicines because of the advantage of decreased toxicity.

The present study reveals for the first time that $\mathrm{AE}$ treatment inhibited the apoptosis of PC-3 cells. Furthermore, $\mathrm{AE}$ treatment protected against Cis-induced kidney and liver injury in a PC-3 cell xenograft model. First, we investigated the effect of $\mathrm{Cis}$ and $\mathrm{AE}$ on the proliferation of PC- 3 cells. AE treatment significantly reduced the viability of PC-3 cells and dramatically deteriorated the cell morphology, inducing cell shrinkage and detachment. Apoptosis is 

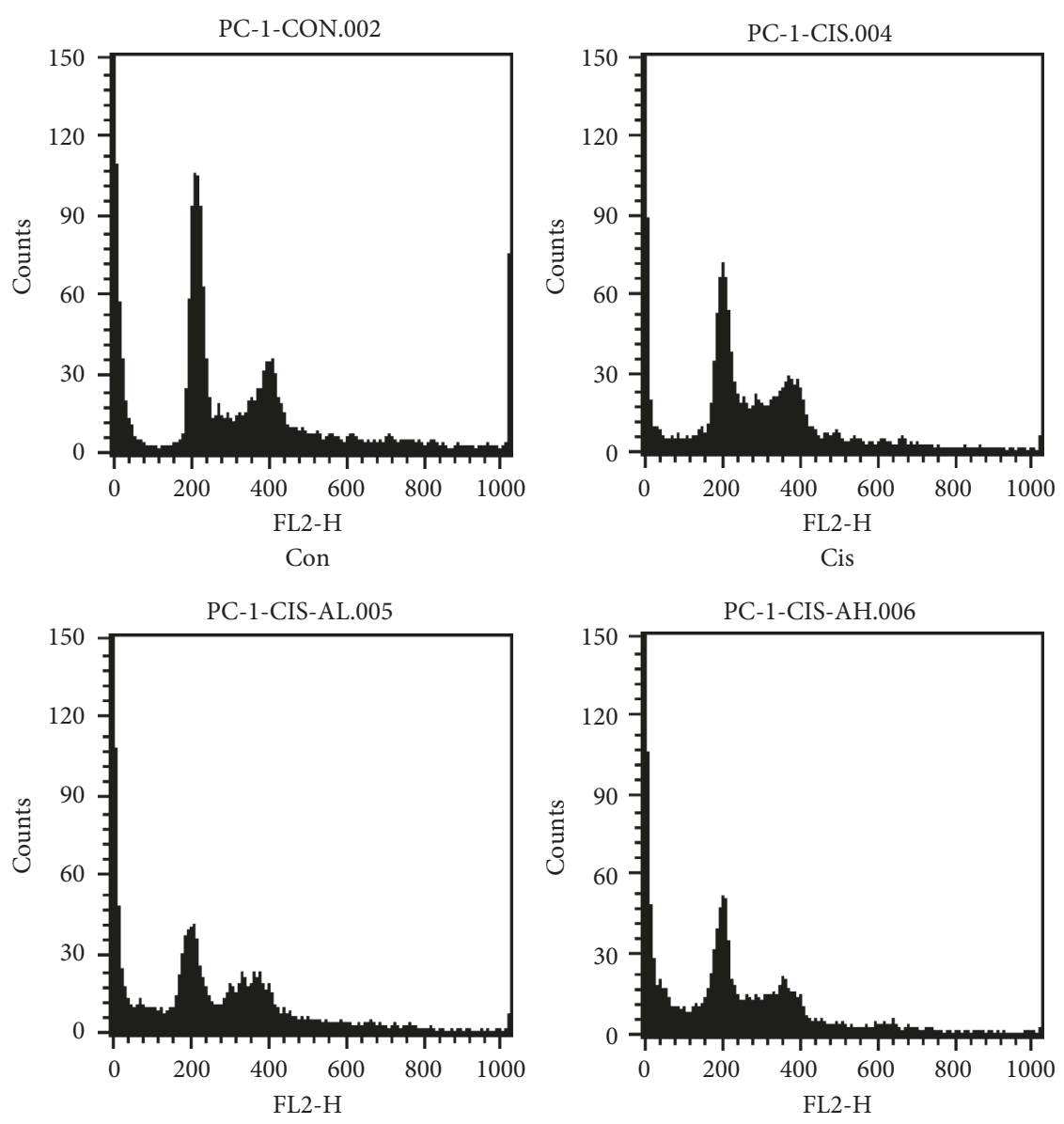

Cis + AEL

$\mathrm{Cis}+\mathrm{AEH}$

(a)

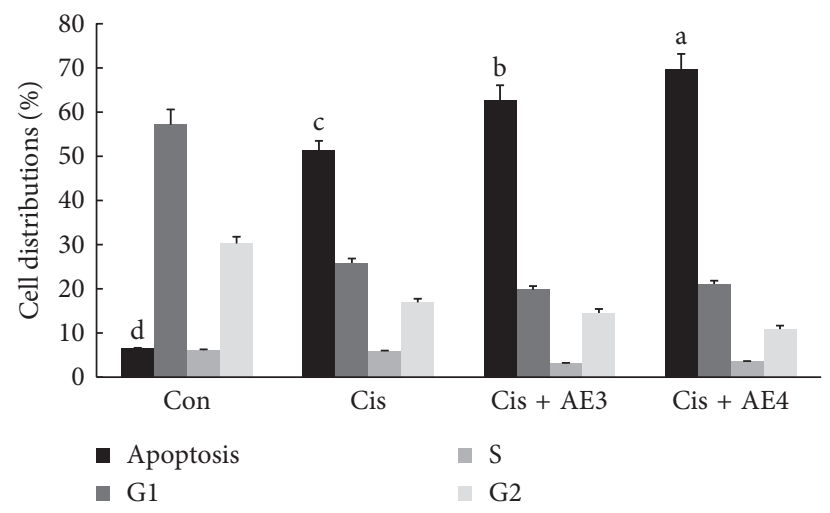

(b)

FIgure 3: Cell cycle analysis of PC-3 prostate cancer cells. Cell cycle distribution was analyzed on a minimum of $1 \times 104$ cells. (a) PC-3 cells treated with cisplatin (Cis) and antler extract (AE). (b) Data from the cell cycle analysis were quantified and presented as a graph to illustrate percentage of cells in each cell cycle phase. Cis (Cis $200 \mu \mathrm{M})$, Cis + AEL (Cis $200 \mu \mathrm{M}$ plus AE low dose, $500 \mu \mathrm{g} / \mathrm{mL})$, and Cis + AEH $(\mathrm{Cis}$ $200 \mu \mathrm{M}+$ AE high dose, $1,000 \mu \mathrm{g} / \mathrm{mL})$.

characterized by a series of typical morphological events such as cell shrinkage and detachment, and our present results are similar to those of Sarastea and Pulkkic [35]. Thus, the effect of AE on cell viability and morphology may suggest that $\mathrm{AE}$ is likely to induce apoptosis of these cells.

In cancer, the normal mechanisms of cell cycle regulation are dysfunctional, with an over proliferation or decreased removal of cells or both [36]. In fact, the suppression of apoptosis during carcinogenesis is thought to play a central role in the development and progression of some cancers [37, 38]. Various molecular mechanisms mediate the suppression of apoptosis by tumor cells. The effect of $\mathrm{Cis}$ and $\mathrm{AE}$ on the cell cycle progression was evaluated in PC-3 cells, and our results are similar to those of 


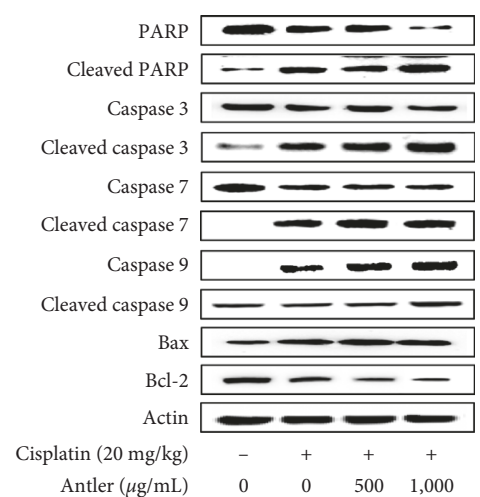

(a)

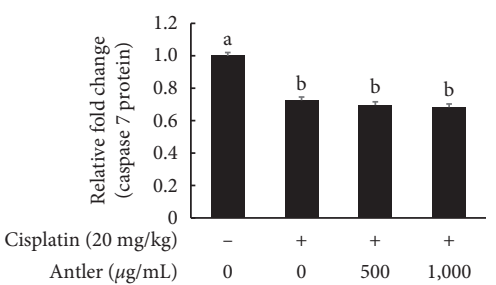

(f)

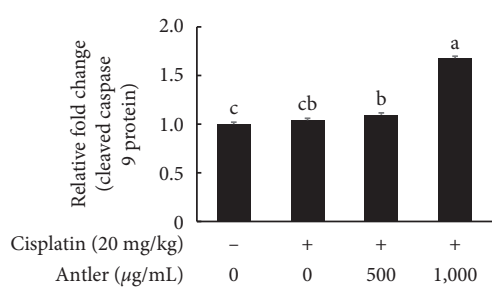

(i)

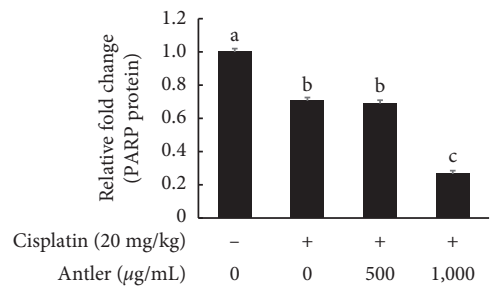

(b)

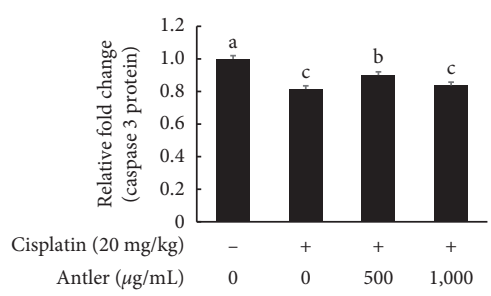

(d)

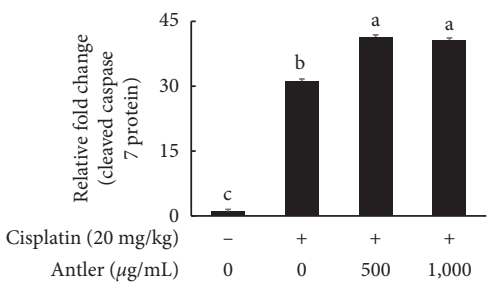

(g)

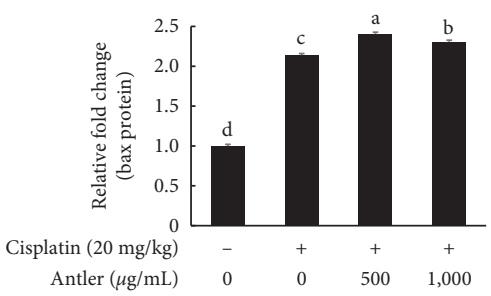

(j)

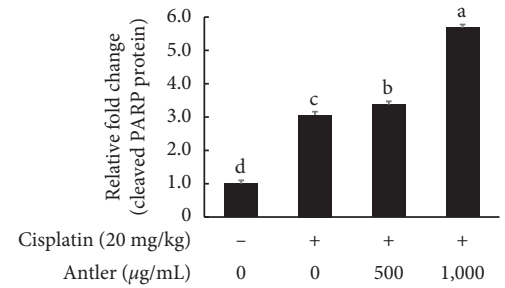

(c)

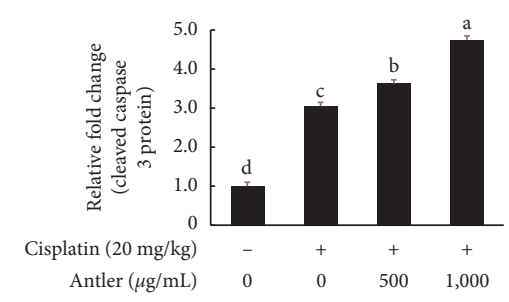

(e)

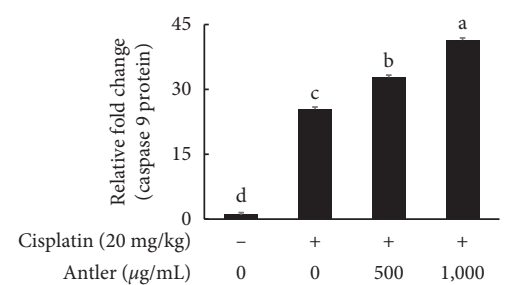

(h)



(k)

FIgUre 4: Apoptotic effect of cisplatin (Cis) and antler extract (AE) on PC-3 prostate cancer cells. $\beta$-Actin was used as a loading control. Results were similar in three independent experiments. ${ }^{a-d}$ Means with different superscript in the same row are different $(p<0.05)$.

Gumulec et al. [34] showing that Cis increased apoptosis of the PC cell model. To improve the current understanding of the apoptotic effect of $\mathrm{Cis}$ and $\mathrm{AE}$, the expression levels of apoptosis-related genes were estimated. The released cytochrome $\mathrm{c}$ interacts with apoptotic protease-activating factor 1 and forms an apoptosome that activates caspase 9, leading to the activation of downstream caspases 3 and 7 and the apoptotic death response [39-42]. The extrinsic pathway is triggered in response to proapoptotic ligands, which bind and activate specific proapoptotic death receptors [36, 37]. In our study, treatment with AEL and $\mathrm{AEH}$ indicated that $\mathrm{AE}$ induces self-cleavage of PARP and caspases 3, 7, and 9 to activate downstream signaling pathway. Cis-induced cell death involves multiple pathways [43]. Khan et al. [44] reported that $\mathrm{Cis}$ alters the mitochondrial membrane potential, activates $\mathrm{Bax}$, reduces $\mathrm{Bcl}-2$, and shifts the $\mathrm{Bax} / \mathrm{Bcl}-2$ ratio in a proapoptotic direction in PC-3 cells. The $\mathrm{AE}+$ Cis groups exhibited significantly decreased and increased protein expression of $\mathrm{Bcl}-2$ and $\mathrm{Bax}$, respectively, compared to that of the Cis group.

Despite being widely used, Cis as chemotherapy is limited by its toxicity $[45,46]$. In the present investigation, Cis-treated nude mice showed a significant decrease in body weight and percentage survival. Cis-induced weight loss might be due to gastrointestinal toxicity and reduction of food ingestion [47]. Pretreatment with AE markedly increased the food intake and body weight, indicating the amelioration of Cis toxicity in the present study, which is similar to the findings of Ahmed et al. [48].

Studies have provided evidence demonstrating that Cisinduced kidney and liver injury is mainly due to oxidative stress $[14,17,18,43,49]$. The result of the present study showed that Cis notably decreased the levels and activities of both SOD and CAT and, thereby, impaired the antioxidant defense mechanisms in the kidneys. Moreover, the lipid peroxidation marker, TBARS, significantly increased 

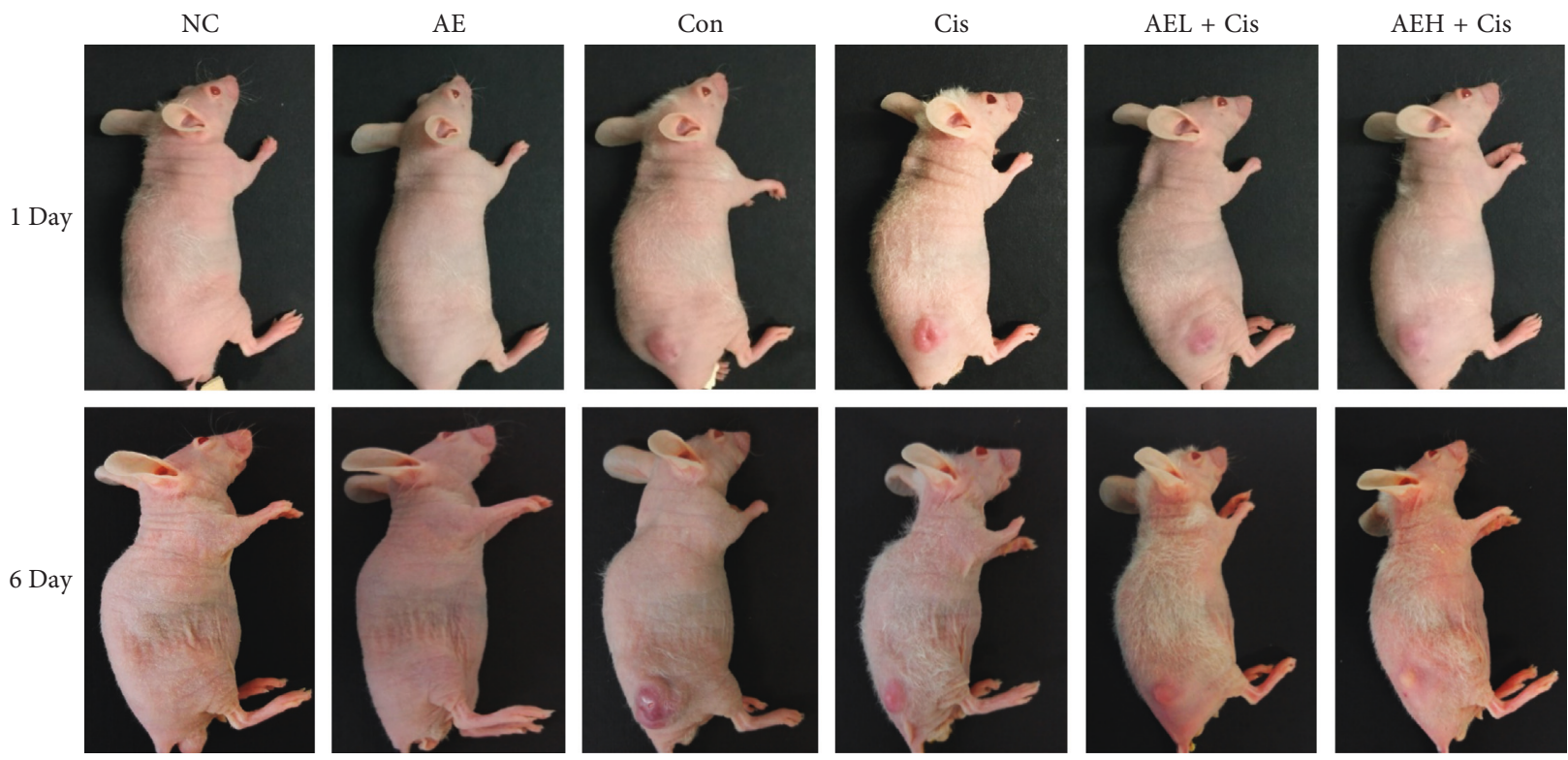

(a)

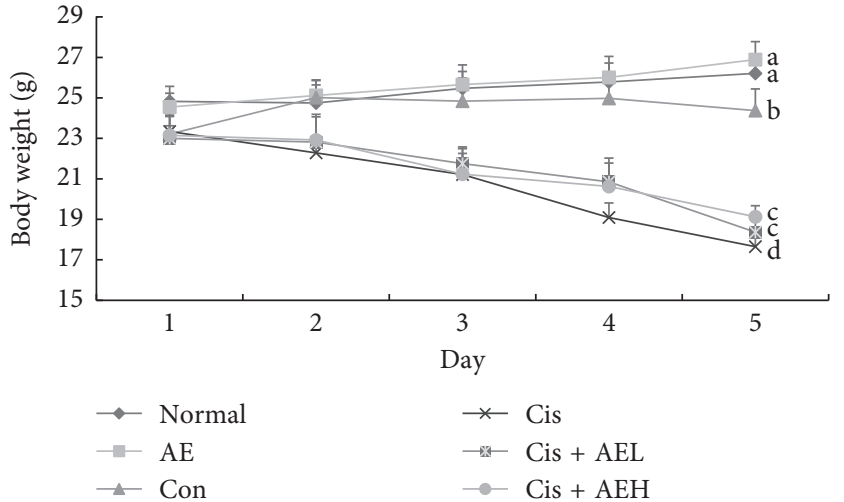

(b)

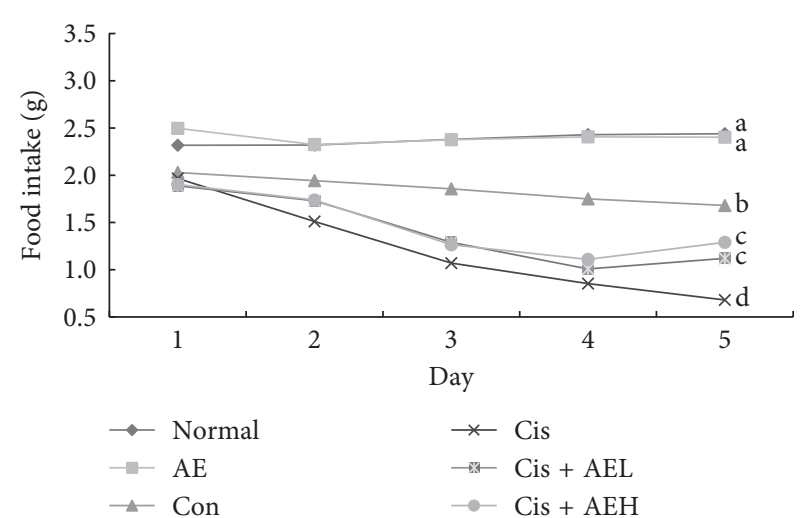

(c)

FIGURE 5: Effect of antler extract (AE) on cisplatin- (Cis-) induced changes in mouse food intake and body weight. (a) Mouse image, (b) food intake, and (c) body weight. Normal control (NC, phosphate-buffered saline (PBS) $200 \mu \mathrm{L}$ ), AE (AE $400 \mathrm{mg} / \mathrm{kg}$ ), Con (PBS $200 \mu \mathrm{L}+$ tumor cells), Cis (Cis $20 \mathrm{mg} / \mathrm{kg}+$ tumor cells), Cis + AEL (AE low dose $200 \mathrm{mg} / \mathrm{kg}+$ Cis $20 \mathrm{mg} / \mathrm{kg}+$ tumor cells), and Cis + AEH (AE high dose $400 \mathrm{mg} / \mathrm{kg}+$ Cis $20 \mathrm{mg} / \mathrm{kg}+$ tumor cells). ${ }^{\mathrm{a}-\mathrm{d}} \mathrm{p}<0.05$ compared with the Cis group.

in the Cis group. Pretreatment with AE improved the Cisinduced nephrotoxicity by significantly enhancing SOD and CAT and significantly decreasing TBARS. Our results appeared to be consistent with many previous findings that indicated the nephrotoxic and hepatotoxic effect of Cis, its association with increased free radical formation, and the subsequent induction of oxidative and nitrosative stress [17, 50-52].

Inflammation plays an important role in the initiation and progression of Cis-induced kidney and liver damage [53-56]. Cis induces the release of a series of proinflammatory cytokines (TNF- $\alpha$, IL- $1 \beta, \mathrm{COX} 2$, and iNOS) and causes the infiltration of leukocytes and macrophages into damaged renal tissues [57]. In addition, apoptosis as well as proinflammatory genes, inducible COX (COX-2) and iNOS, may have critical roles in the mechanism of Cis-induced acute kidney and liver damage $[16,49,58]$. The present study shows that Cis-induced liver injury is accompanied by an inflammatory reaction, evidenced by increased formation of the proinflammatory cytokines TNF- $\alpha$, IL- $1 \beta$, and IL- 6 , as well as increased COX-2 and iNOS expression. Cis + AE significantly decreased the expression levels of the inflammation-related genes. These results are consistent with the findings of many recently published studies [48, 51, 52, 59-61].

Furthermore, inflammatory cells in the kidneys, as evidenced by light microscopic examination (H\&E staining) of kidney tissues, were similar to those observed by Sahu et al. [16]. In addition, our data also suggest that Cis caused kidney pathologies including proteinaceous casts in the tubular lumen, detachment of tubular cells, from the basement membrane, and tubular necrosis.

The Cis + AE groups showed less damage than the Cis group did. An et al. [62] and Atasayar et al. [63] found that 


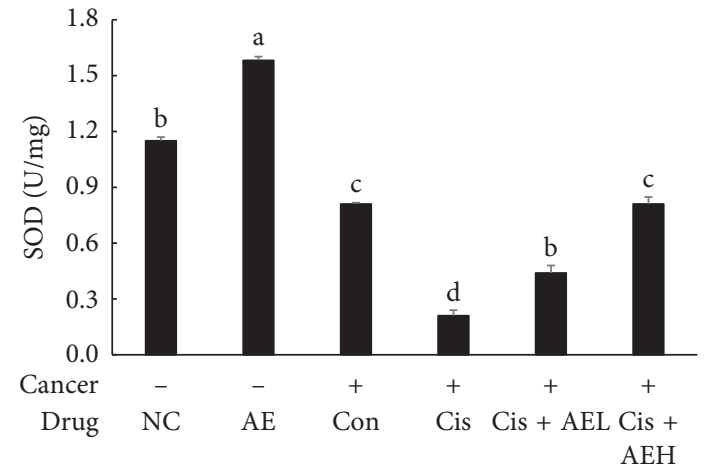

(a)

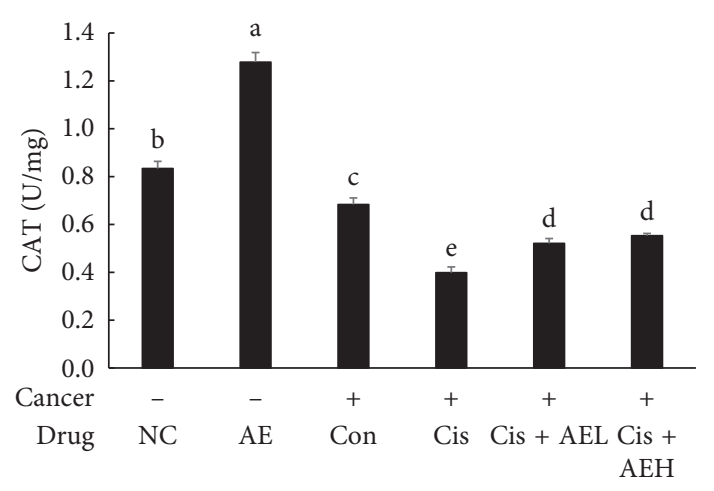

(b)

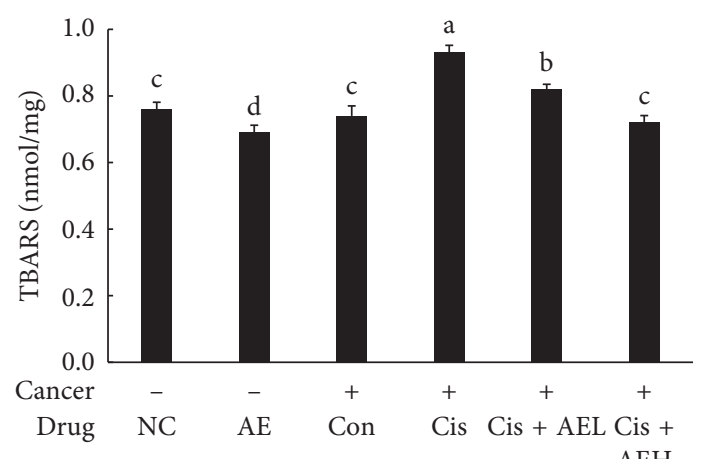

(c)

FIGURE 6: Effect of cisplatin (Cis) and antler extract (AE) treatment on superoxide dismutase (SOD), catalase (CAT), and thiobarbituric acid reactive substances (TBARS) activity. Normal control (NC, phosphate-buffered saline (PBS), $200 \mu \mathrm{L}), \mathrm{AE}$ (AE $400 \mathrm{mg} / \mathrm{kg}$ ), Con (PBS $200 \mu \mathrm{L}$ + tumor cells), Cis (Cis $20 \mathrm{mg} / \mathrm{kg}$ + tumor cells), Cis + AEL (AE low dose $200 \mathrm{mg} / \mathrm{kg}+\mathrm{Cis} 20 \mathrm{mg} / \mathrm{kg}+$ tumor cells), and Cis + AEH (AE highdose $400 \mathrm{mg} / \mathrm{kg}+$ Cis $20 \mathrm{mg} / \mathrm{kg}+$ tumor cells). ${ }^{\mathrm{a}-\mathrm{d}} p<0.05$ compared with the Cis group.

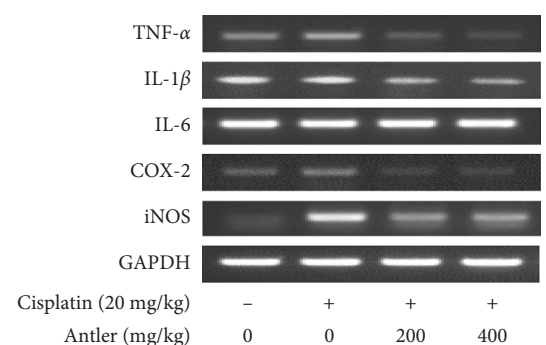

(a)

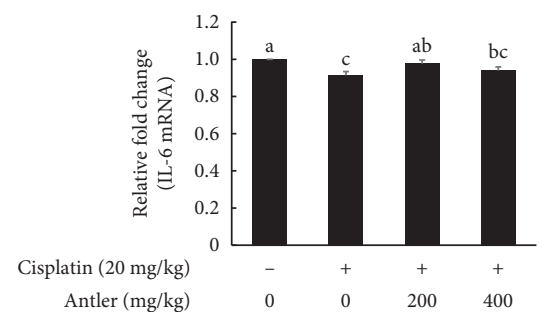

(d)

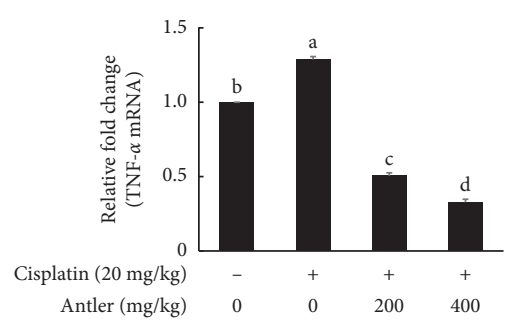

(b)

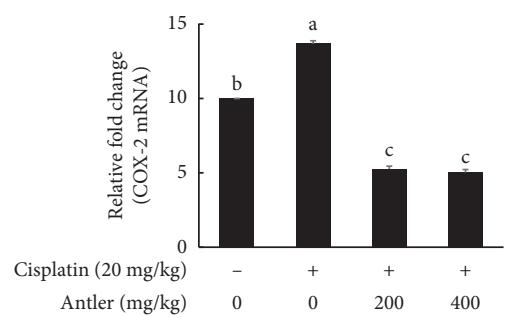

(e)

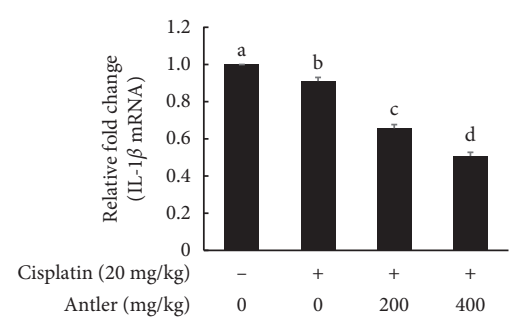

(c)

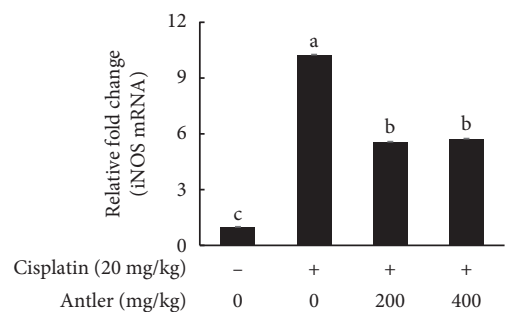

(f)

Figure 7: Continued. 


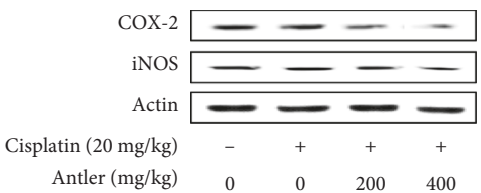

(g)



(h)

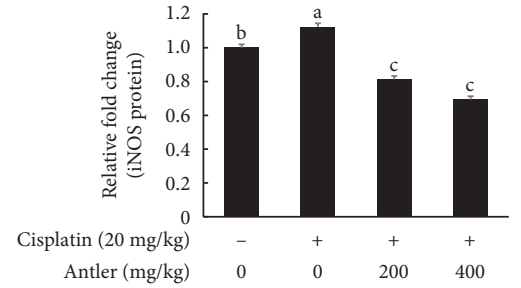

(i)

FIGURE 7: Expression of inflammation-related gene expression in kidney tissues using reverse transcription-polymerase chain reaction (RTPCR) and western blotting. Glyceraldehyde 3-phosphate dehydrogenase (GAPDH) was used as a control. Results were similar in three independent experiments. Normal control (NC, phosphate-buffered saline (PBS), $200 \mu \mathrm{L}$ ), AE (AE $400 \mathrm{mg} / \mathrm{kg}), \mathrm{Con}(\mathrm{PBS} 200 \mu \mathrm{L}+\mathrm{tumor}$ cells), Cis (Cis $20 \mathrm{mg} / \mathrm{kg}+$ tumor cells), Cis + AEL (AE low dose $200 \mathrm{mg} / \mathrm{kg}+$ Cis $20 \mathrm{mg} / \mathrm{kg}+$ tumor cells), and Cis + AEH (AE high dose $400 \mathrm{mg} / \mathrm{kg}+$ Cis $20 \mathrm{mg} / \mathrm{kg}+$ tumor cells). ${ }^{\mathrm{a}-\mathrm{d}}$ Means with different superscript in the same row are different $(p<0.05)$.

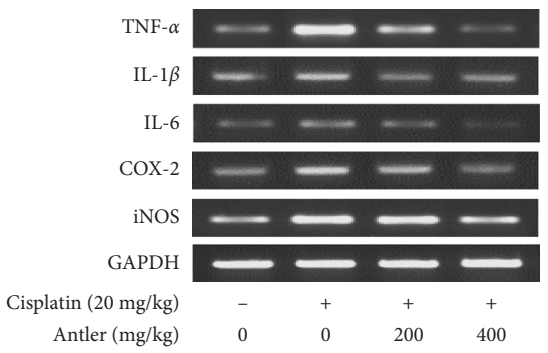

(a)

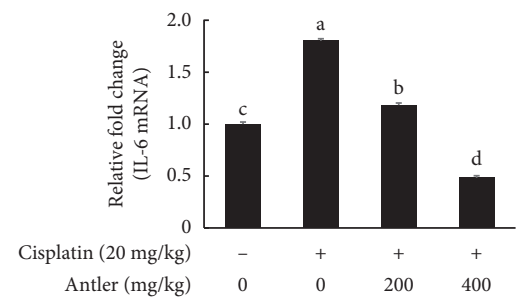

(d)

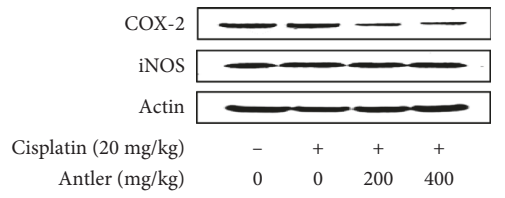

(g)

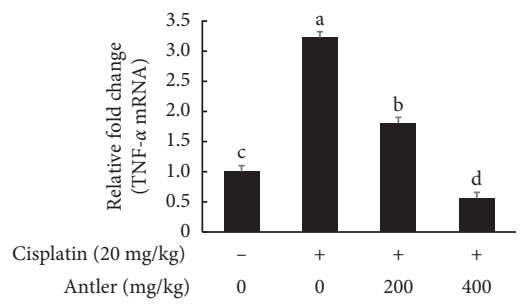

(b)

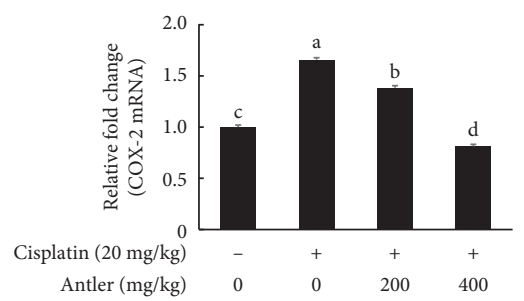

(e)

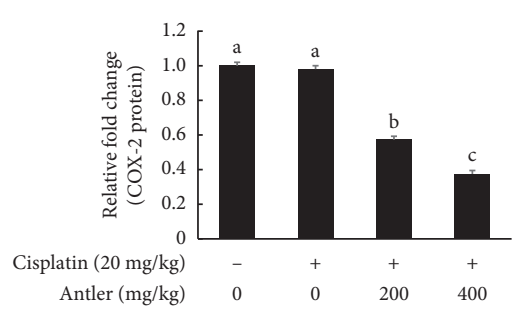

(h)



(c)

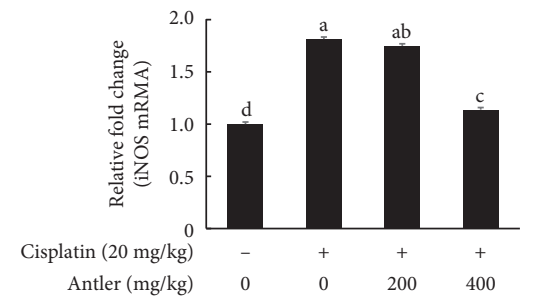

(f)

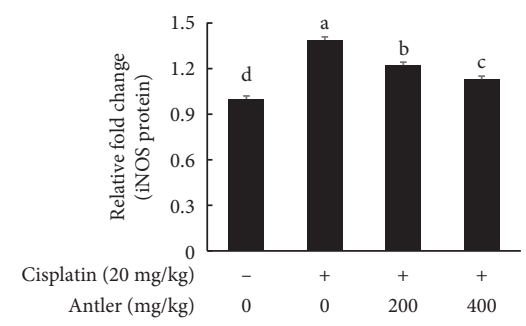

(i)

FIGURE 8: Expression of inflammation-related gene expression in the liver tissue using reverse transcription-polymerase chain reaction (RTPCR) and western blotting. Glyceraldehyde 3-phosphate dehydrogenase (GAPDH) was used as a control. Results were similar in three independent experiments. Normal control (NC, phosphate-buffered saline (PBS) $200 \mu \mathrm{L}$ ), AE (AE $400 \mathrm{mg} / \mathrm{kg}$ ), Con (PBS $200 \mu \mathrm{L}+\mathrm{tumor}$ cells), Cis (Cis $20 \mathrm{mg} / \mathrm{kg}+$ tumor cells), Cis + AEL (AE low dose $200 \mathrm{mg} / \mathrm{kg}+$ Cis $20 \mathrm{mg} / \mathrm{kg}+$ tumor cells), and Cis + AEH (AE high dose $400 \mathrm{mg} / \mathrm{kg}+$ Cis $20 \mathrm{mg} / \mathrm{kg}+$ tumor cells). ${ }^{\mathrm{a}-\mathrm{d}}$ Means with different superscript in the same row are different $(p<0.05)$.

the histology of renal sections exhibited remarkable vacuolation, necrosis, desquamation of epithelial cells, and proteinaceous casts in renal tubules after intraperitoneal treatment with single doses of Cis. Cisinduced hepatotoxicity is mainly characterized by multiple histopathological lesions, swelling of the hepatocytes with compressed blood sinusoid, fatty infiltration, prominence of Kupffer cells near the mild to moderate congestion of the HA, sinusoids, and PV, with dilatation of the PV and moderate disorganization of hepatic cords. A marked recovery was observed in the markers of liver function after combination treatment with Cis + AE. Our results are consistent with those results of Dkhil et al. [61] and Palipoch and Punsawad [19]. Therefore, we suggest 

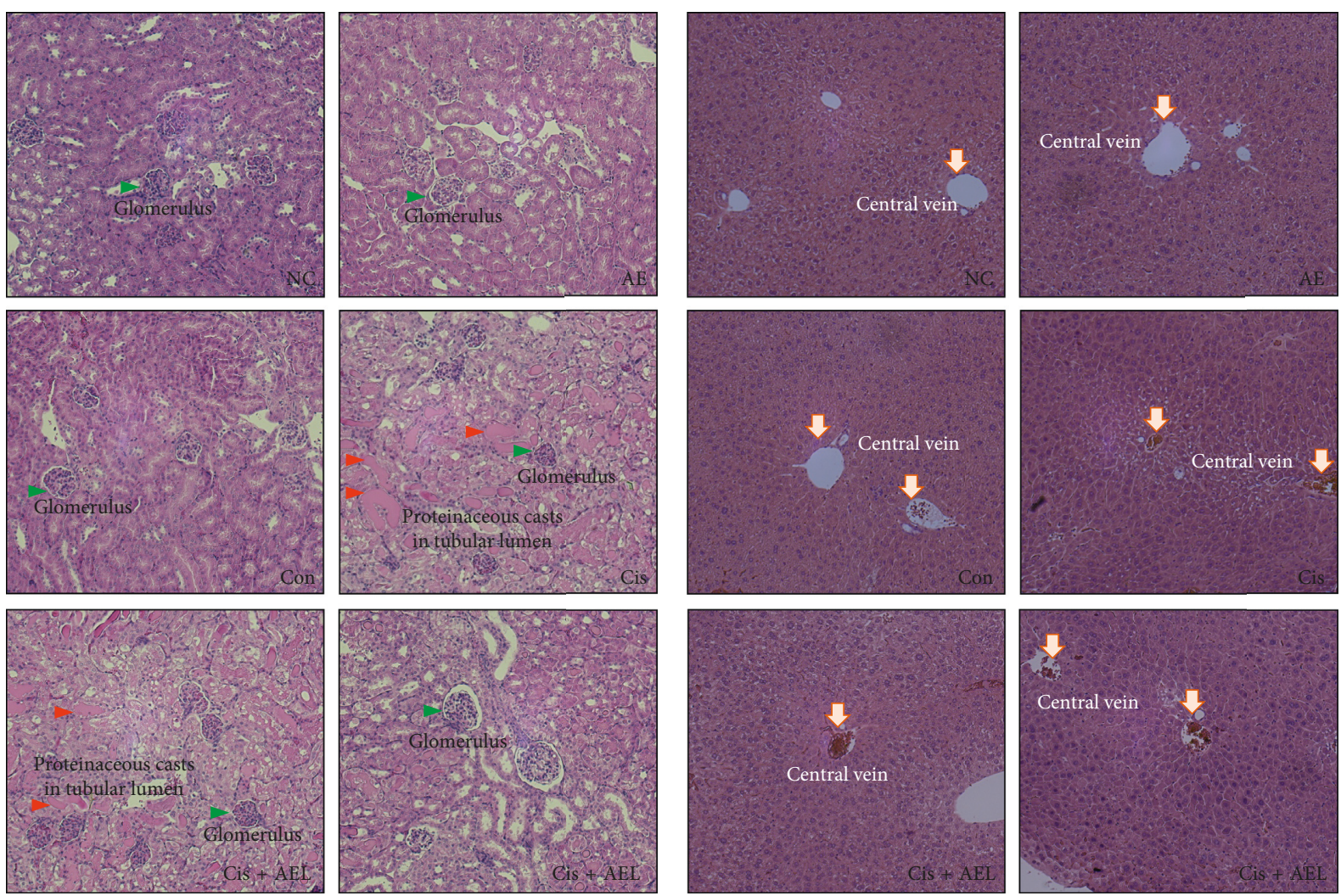

(a)

(b)

FIGURE 9: Histological alterations in the kidney and liver tissue of the cisplatin- (Cis-) treated group. Hematoxylin and eosin (H\&E staining, $100 \times$ magnification). (a) Kidney and (b) liver. $\mathrm{CV}=$ central vein; normal control (NC, phosphate-buffered saline (PBS), $200 \mu \mathrm{L}), \mathrm{AE}(\mathrm{AE}$ $400 \mathrm{mg} / \mathrm{kg}$ ), Con (PBS $200 \mu \mathrm{L}+$ tumor cells), Cis (Cis $20 \mathrm{mg} / \mathrm{kg}+$ tumor cells), Cis + AEL (AE low dose $200 \mathrm{mg} / \mathrm{kg}+\mathrm{Cis} 20 \mathrm{mg} / \mathrm{kg}+\mathrm{tumor}$ cells), and Cis + AEH (AE high dose $400 \mathrm{mg} / \mathrm{kg}+$ Cis $20 \mathrm{mg} / \mathrm{kg}+$ tumor cells).

that the use of $\mathrm{AE}$ in combination with Cis in antiprostate cancer therapy may contribute to reducing the Cisinduced toxicities.

\section{Conclusions}

In conclusion, the protective effects of $\mathrm{AE}$ against Cisinduced kidney and liver injury were likely mediated by the downregulation of apoptosis, oxidative stress, and inflammation and improvement of histological changes in vivo and in vitro. From these results, we suggest that the use of $\mathrm{AE}$ in combination with Cis in antiprostate cancer therapy may contribute to reducing the Cis-induced toxicities.

\section{Data Availability}

The data used to support the findings of this study are available from the corresponding author upon request.

\section{Disclosure}

This research was awarded the Best Poster Award at the 2017 International Symposium and Annual Meeting of Korean Society of Food Science and Technology.

\section{Conflicts of Interest}

The authors declare that there are no conflicts of interests regarding the publication of this paper.

\section{Acknowledgments}

This research was supported by Basic Science Research Program through the National Research Foundation of Korea (NRF) funded by the Ministry of Education, Science and Technology (NRF-2017R1D1A1B03036247), the Korea Institute of Planning and Evaluation for Technology in Food, Agriculture, Forestry and Fisheries (IPET) through the AgriBio Industry Technology Development Program (116083-3) funded by the Ministry of Agriculture, Food and Rural Affairs (MAFRA) and the Functional Districts of the Science Belt support program, Ministry of Science and ICT, Republic of Korea (2017K000017).

\section{Supplementary Materials}

Protective effect of Sika deer (Cervus nippon) velvet antler in vitro and in vivo. (Supplementary Materials) 


\section{References}

[1] A. Snyder, J. E. Tepper, and S. Slovin, "Perspectives on immunotherapy in prostate cancer and solid tumors: where is the future?," Seminars in Oncology, vol. 40, no. 3, pp. 347-360, 2013.

[2] F. Lamoureux, C. Thomas, M. J. Yin et al., "A novel HSP90 inhibitor delays castrate-resistant prostate cancer without altering serum PSA levels and inhibits osteoclastogenesis," Clinical Cancer Research, vol. 17, no. 8, pp. 2301-2313, 2011.

[3] M. E. Gleave, N. Bruchovsky, M. J. Moore, and P. Venner, "Prostate cancer: 9. Treatment of advanced disease," Canadian Medical Association Journal, vol. 160, no. 2, pp. 225-232, 1999.

[4] J. P. Moreau, P. Delavault, and J. Blumberg, "Luteinizing hormone- releasing hormone agonists in the treatment of prostate cancer: a review of their discovery, development, and place in therapy," Clinical Therapeutics, vol. 28, no. 10, pp. 1485-1508, 2006.

[5] S. Huang, Z. Yang, Y. Ma, and S. Wang, "miR-101 enhances cisplatin- induced DNA damage through decreasing nicotinamide adenine dinucleotide phosphate levels by directly repressing Tp53-induced glycolysis and apoptosis regulator expression in prostate cancer cells," DNA and Cell Biology, vol. 36, no. 4, pp. 303-310, 2017.

[6] M. Chovanec, Z. Cierna, V. Miskovska et al., "Prognostic role of programmed-death ligand 1 (PD-L1) expressing tumor infiltrating lymphocytes in testicular germ cell tumors," Onceotarget, vol. 8, no. 13, pp. 21794-21805, 2017.

[7] G. L. Yang, L. H. Zhang, Q. Liu et al., "A novel treatment strategy for newly diagnosed high-grade $\mathrm{T} 1$ bladder cancer: gemcitabine and cisplatin adjuvant chemotherapy-A singleinstitution experience," Urologic Oncology: Seminars and Original Investigations, vol. 35, no. 2, pp. 38.e9-e15, 2017.

[8] T. Sugiyama, A. Okamoto, T. Enomoto et al., "Randomized phase III trial of irinotecan plus cisplatin compared with paclitaxel plus carboplatin as first-line chemotherapy for ovarian clear cell carcinoma: JGOG3017/GCIG trial," Journal of Clinical Oncology, vol. 34, no. 24, pp. 2881-2887, 2016.

[9] G. Cancello, V. Bagnardi, C. Sangalli et al., "Phase II study with epirubicin, cisplatin, and infusional fluorouracil followed by weekly paclitaxel with metronomic cyclophosphamide as a preoperative treatment of triple-negative breast cancer," Clinical Breast Cancer, vol. 15, no. 4, pp. 259-265, 2015.

[10] M. Joerger, J. von Pawel, S. Kraff et al., "Open-label, randomized study of individualized, pharmacokinetically (PK)guided dosing of paclitaxel combined with carboplatin or cisplatin in patients with advanced non-small-cell lung cancer (NSCLC)," Annals of Oncology, vol. 27, no. 10, pp. 1895-1902, 2016.

[11] M. Galanski, M. A. Jakupec, and B. K. Keppler, "Update of the preclinical situation of anticancer platinum complexes: novel design strategies and innovative analytical approaches," Current Medical Chemistry, vol. 12, no. 18, pp. 2075-2094, 2005.

[12] L. Galluzzi, L. Senovilla, I. Vitale et al., "Molecular mechanisms of cisplatin resistance," Oncogene, vol. 31, no. 15, pp. 1869-1883, 2012.

[13] I. Arany and R. L. Safirstein, "Cisplatin nephrotoxicity," Seminars in Nephrology, vol. 23, no. 5, pp. 460-464, 2002.

[14] Y. Liao, X. Lu, C. Lu, G. Li, Y. Jin, and H. Tang, "Selection of agents for prevention of cisplatin-induced hepatotoxicity," Pharmacology Research, vol. 57, no. 2, pp. 125-131, 2008.
[15] P. D. Sanchez-Gonzalez, F. J. Lopez-Hernandez, J. M. LopezNovoa, and A. I. Morales, "An integrative view of the pathophysiological events leading to cisplatin nephrotoxicity," Critical Reviews in Toxicology, vol. 41, no. 10, pp. 803821, 2011.

[16] B. D. Sahu, J. M. Kumar, and R. Sistla, "Baicalein, a bioflavonoid, prevents cisplatin-induced acute kidney injury by up-regulating antioxidant defenses and down-regulating the MAPKs and NF-kB pathways," PLoS One, vol. 10, no. 7, Article ID e0134139, 2015.

[17] B. Dl Sahu, M. Kuncha, G. J. Sindhura, and R. Sistla, "Hesperidin attenuates cisplatin-induced acute renal injury by decreasing oxidative stress, inflammation and DNA damage," Phytomedicine, vol. 20, no. 5, pp. 453-460, 2013.

[18] S. Işeri, F. Ercan, N. Gedik, M. Yüksel, and İ. Alican, "Simvastatin attenuates cisplatin-induced kidney and liver damage in rats," Toxicology, vol. 230, no. 2-3, pp. 256-264, 2007.

[19] S. Palipoch and C. Punsawad, "Biochemical and histological study of rat liver and kidney injury induced by cisplatin," Journal of Toxicologic Pathology, vol. 26, no. 3, pp. 293-299, 2013.

[20] Y. Li, Y. Zhao, R. Tang, and X. Qu, "Preventive and therapeutic effects of antler collagen on osteoporosis in ovariectomized rats," African Journal of Biotechnology, vol. 9, no. 38, pp. 6437-6441, 2010.

[21] M. J. Shao, S. R. Wang, M. J. Zhao et al., "The Effects of Velvet Antler of Deer on Cardiac Functions of Rats with Heart Failure following Myocardial Infarction," Evidence Based Complementary and Alternative Medicine, vol. 2012, Article ID 825056, 5 pages, 2012.

[22] R. Karawita, P. J. Park, N. Siriwardhana et al., "Angiotensin I-converting enzyme (ACE) inhibitory activity of elk (Cervus elaphus) velvet Antler," Journal of Food Science and Nutrition, vol. 10, no. 3, pp. 239-243, 2005.

[23] J. H. Kim, Y. I. Yang, J. H. Ahn, J. G. Lee, K. T. Lee, and J. H. Choi, "Deer (Cervus elaphus) antler extract suppresses adhesion and migration of endometriotic cells and regulates MMP-2 and MMP-9 expression," Journal of Ethnopharmacology, vol. 140, no. 2, pp. 391-397, 2012.

[24] Y. Tang, B. T. Jeon, Y. Wang et al., "First evidence that Sika deer (Cervus nippon) velvet antler extract suppresses migration of human prostate cancer cells," Korean Journal for Food Science of Animal Resources, vol. 35, no. 4, pp. 507-514, 2015.

[25] Y. Tang, B. T. Jeon, Y. Wang et al., "First evaluation of the biologically active substances and antioxidant potential of regrowth velvet antler by means of multiple biochemical assays," Journal of Chemistry, vol. 2015, Article ID 975292, 7 pages, 2015.

[26] M. R. Zirak, R. Rahimian, M. Ghazi-Khansari et al., "Tropisetron attenuates cisplatin-induced nephrotoxicity in mice," European Journal of Pharmacology, vol. 738, pp. 222-229, 2014.

[27] Y. C. Hung, G. S. Huang, L. W. Lin, M. Y. Hong, and P. S. Se, "Thea sinensis melanin prevents cisplatin-induced nephrotoxicity in mice," Food and Chemical Toxicology, vol. 45, no. 7, pp. 1123-1130, 2007.

[28] M. Ueki, M. Ueno, J. Morishita, and N. Maekawa, "Curcumin ameliorates cisplatin-induced nephrotoxicity by inhibiting renal inflammation in mice," Journal of Bioscience and Bioengineering, vol. 115, no. 5, pp. 547-551, 2013.

[29] Q. Wu, M. Kohli, H. R. Bergen et al., "Preclinical evaluation of the supercritical extract of azadirachta indica (neem) leaves in vitro and in vivo on inhibition of prostate cancer tumor 
growth," Molecular Cancer Therapeutics, vol. 13, no. 5, pp. 1067-1077, 2014.

[30] F. Yang, L. Song, H. Wang, Z. Xu, and N. Xing, "Combination of quercetin and 2-methoxyestradiol enhances inhibition of human prostate cancer LNCaP and PC-3 cells xenograft tumor growth," PLoS One, vol. 10, no. 5, Article ID e0128277, 2015.

[31] A. Ehteda, P. Galettis, K. Pillai, and D. L. Morris, "Combination of albendazole and 2-methoxyestradiol significantly improves the survival of HCT-116 tumor-bearing nude mice," BMC Cancer, vol. 13, no. 1, p. 86, 2013.

[32] A. Gilbey and J. D. Perezgonzalez, "Health benefits of deer and elk velvet antlersupplements: a systematic review of randomised controlled studies," New Zealand Medical Journal, vol. 125, no. 1367, pp. 80-86, 2012.

[33] E. K. Kim, W. B. Lee, S. H. Moon et al., "Free radical scavenging activity by ESR spectroscopy and neuroprotective effect on $\mathrm{H}_{2} \mathrm{O}_{2}$-induced damage in PC-12 cells of enzymatic from Korean elk velvet antler," Journal of Food Biochemistry, vol. 33, no. 6, pp. 895-912, 2009.

[34] J. Gumulec, J. Balvan, M. Sztalmachova et al., "Cisplatinresistant prostate cancer model: differences in antioxidant system, apoptosis and cell cycle," International Journal of Oncology, vol. 44, no. 3, pp. 923-933, 2014.

[35] A. Sarastea and K. Pulkkic, "Morphologic and biochemical hallmarks of apoptosis," Cardiovascular Research, vol. 45, no. 3, pp. 528-537, 2000.

[36] K. L. King and J. A. Cidlowski, "Cell cycle regulation and apoptosis," Annual Review Physiology, vol. 60, no. 1, pp. 601-617, 1998.

[37] J. F. Kerr, C. M. Winterford, and B. V. Harmon, "Apoptosis. Its significance in cancer and cancer therapy," Cancer, vol. 73, no. 8, pp. 2013-2026, 1994.

[38] D. Hanahan and R. A. Weinberg, "The hallmarks of cancer," Cell, vol. 100, no. 1, pp. 57-70, 2000.

[39] S. Gurumurthy, K. M. Vasudevan, and V. M. Rangnekar, "Regulation of apoptosis in prostate cancer," Cancer Metastasis Review, vol. 20, no. 3-4, pp. 225-243, 2001.

[40] S. W. Fesik, "Promoting apoptosis as a strategy for cancer drug discovery," Nature Review Cancer, vol. 5, no. 11, pp. 876-885, 2005.

[41] N. V. Guseva, A. F. Taghiyev, O. W. Rokhlin, and M. B. Cohen, "Death receptor-induced cell death in prostate cancer," Journal of Cellular Biochemistry, vol. 91, no. 1, pp. 70-99, 2004.

[42] A. Ashkenazi, "Targeting death and decoy receptors of the tumour-necrosis factor superfamily," Nature Review Cancer, vol. 2, no. 6, pp. 420-430, 2002.

[43] K. P. Kang, S. K. Park, D. H. Kim et al., "Luteolin ameliorates cisplatin-induced acute kidney injury in mice by regulation of p53-dependent renal tubular apoptosis," Nephrology, Dialysis and Transplantation, vol. 26, no. 3, pp. 814-822, 2011.

[44] M. A. H. Khan, J. Liu, G. Kumar, S. X. Skapek, J. R. Falck, and J. D. Imig, "Novel orally active epoxyeicosatrienoic acid (EET) analogs attenuate cisplatin nephrotoxicity," FASEB Journal, vol. 27, no. 8, pp. 2946-2956, 2013.

[45] N. A. Dos Santos, M. A. Carvalho Rodrigues, N. M. Martins, and A. C. dos Santos, "Cisplatin-induced nephrotoxicity and targets of nephroprotection: an update," Archives of Toxicology, vol. 86, no. 8, pp. 1233-1250, 2012.

[46] Y. Kidera, H. Kawakami, T., Sakiyama, K. Okamoto, and K. Tanaka, "Risk factors for cisplatin-induced nephrotoxicity and potential of magnesium supplementation for renal protection," PLoS One, vol. 9, no. 7, Article ID e101902, 2014.
[47] O. Mora Lde, L. M. Antunes, H. D. Francescato, and L. Bianchi Mde, "The effects of oral glutamine on cisplatininduced nephrotoxicity in rats," Pharmacological Research, vol. 47, no. 6, pp. 517-522, 2003.

[48] L. A. Ahmed, N. I. Shehata, N. F. Abdelkader, and M. M. Khattab, "Tempol, a superoxide dismutase mimetic agent, ameliorates cisplatin-induced nephrotoxicity through alleviation of mitochondrial dysfunction in mice," PLoS One, vol. 9, no. 10, Article ID e108889, 2014.

[49] S. H. Kim, K. O. Hong, W. Y. Chung, J. K. Hwang, and K. K. Park, "Abrogation of cisplatin-induced hepatotoxicity in mice by xanthorrhizol is related to its effect on the regulation of gene transcription," Toxicology and Applied Pharmacology, vol. 196, no. 3, pp. 814-822, 2004.

[50] R. Bentli, H. Parlakpinar, A. Polat, E. Samdanci, M. E. Sarihan, and M. Sagir, "Molsidomine prevents cisplatin induced hepatotoxicity," Archives of Medical Research, vol. 44, no. 7, pp. 521-528, 2013.

[51] H. A. Omar, W. R. Mohamed, H. H. Arab, and S. A. Arafa, "Tangeretin alleviates cisplatin-induced acute hepatic injury in rats: targeting MAPKs and apoptosis," PLoS One, vol. 11, no. 3, Article ID e0151649, 2016.

[52] M. U. Rehman, N. Ali, and S. Rashid, "Alleviation of hepatic injury by chrysin in cisplatin administered rats: probable role of oxidative and inflammatory marker," Pharmacological Report, vol. 66, no. 6, pp. 1050-1059, 2014.

[53] N. A. El-Shitany and B. Eid, "Proanthocyanidin protects against cisplatin-induced oxidative liver damage through inhibition of inflammation and NF- $\kappa /$ TLR-4 pathway," Environmental Toxicology, vol. 32, no. 7, pp. 1952-1963, 2017.

[54] N. Pabla and Z. Dong, "Cisplatin nephrotoxicity: mechanisms and renoprotective strategies," Kidney International, vol. 73, no. 9, pp. 994-1007, 2008.

[55] G., Ramesh and W. B. Reeves, "TNF-alpha mediates chemokine and cytokine expression and renal injury in cisplatin nephrotoxicity," Journal of Clinical Investigation, vol. 110, no. 6, pp. 835-842, 2002.

[56] M. J. Sung, D. H. Kim, Y. J. Jung, K. P. Kang, A. S. Lee, and S. Lee, "Genistein protects the kidney from cisplatin-induced Injury," Kidney International, vol. 74, no. 12, pp. 1538-1547, 2008.

[57] C. E. Guerrero-Beltrán, P. Mukhopadhyay, B. Horváth, M. Rajesh, E. Tapia, and I. García-Torres, "Sulforaphane, a natural constituent of broccoli, prevents cell death and inflammation in nephropathy," Journal of Nutritional Biochemistry, vol. 23, no. 5, pp. 494-500, 2012.

[58] F. M. Kandemir, F. Benzer, M. Ozkaraca, S. Ceribasi, N. Cikcikoglu Yildirim, and N. Ozdemir, "Protective antioxidant effects of grape seed extract in a cisplatin-induced hepatotoxicity model in rabbits," Revue De Medecine Veterinaire, vol. 163, no. 11, pp. 539-545, 2012.

[59] B. I. Ognjanović, N. Z. Djordjević, M. M. Matić et al., "Lipid peroxidative damage on cisplatin exposure and alterations in antioxidant defense system in rat kidneys: a possible protective effect of selenium," International Journal of Molecular Sciences, vol. 13, no. 2, pp. 1790-1803, 2012.

[60] A. L. Al-Malki and A. A. Sayed, "Thymoquinone attenuates cisplatin induced hepatotoxicity via nuclear factor kappa-b," BMC Complementary and Alternative Medicine, vol. 14, no. 1, p. 282, 2014.

[61] M. A. Dkhil, S. Al-Quraishy, A. M. Aref, M. S. Othman, K. M. El-Deib, and A. E. Abdel Moneim, "The potential role of Azadirachta indica treatment on cisplatin-induced hepatotoxicity and oxidative stress in female rats," Oxidative 
Medicine and Cell Longevity, vol. 2013, Article ID 741817, 9 pages, 2013.

[62] Y. An, H. Xin, W. Yan, and X. Zhou, "Amelioration of cisplatin-induced nephrotoxicity by pravastatin in mice," Experimental and Txicologic Pthology, vol. 63, no. 3, pp. 215-219, 2011.

[63] S. Atasayar, H. Gürer-Orhan, H. Orhan, B. Gürer, G. Girgin, and H. Özgüneş, "Preventive effect of amino guanidine compared to vitamin $\mathrm{E}$ and $\mathrm{C}$ on cisplatin-induced nephrotoxicity in rats," Experimental and Toxicologic Pathology, vol. 61, no. 1, pp. 23-32, 2009. 

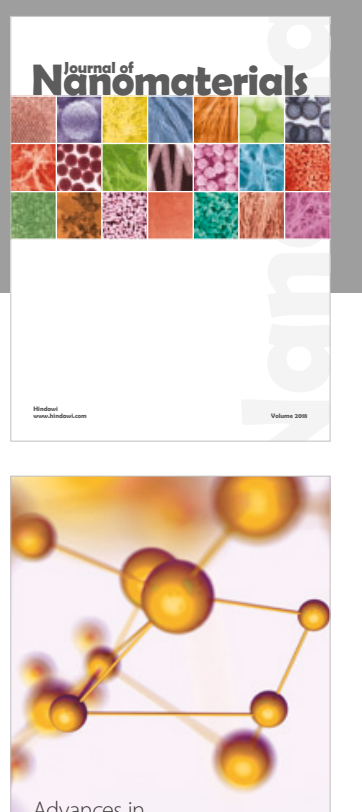

Physical Chemistry
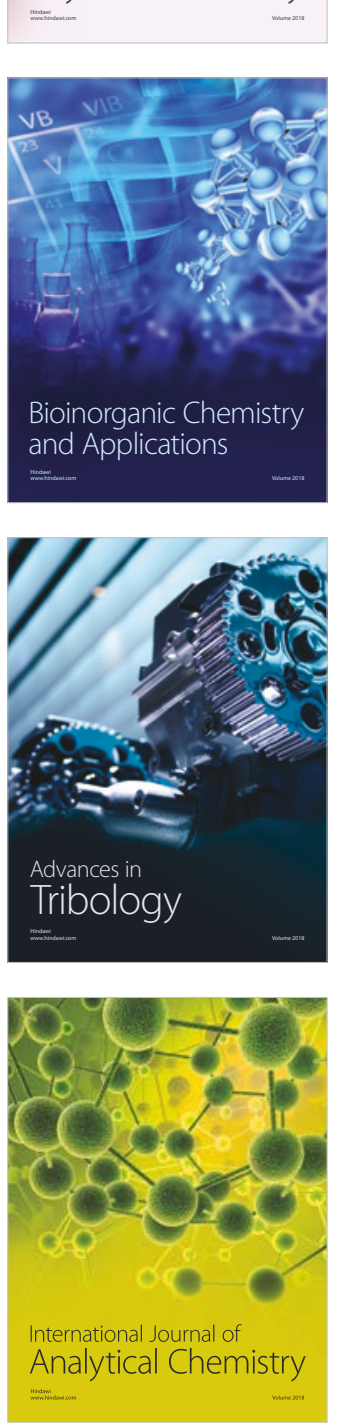

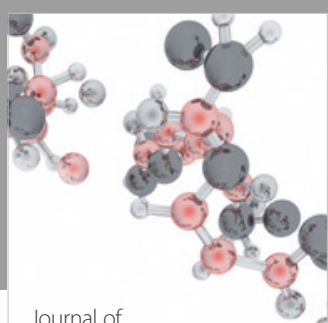

Analytical Methods

in Chemistry

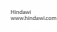

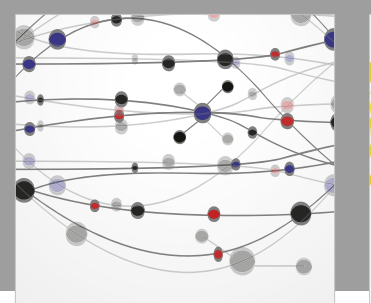

The Scientific World Journal



Journal of

Applied Chemistry
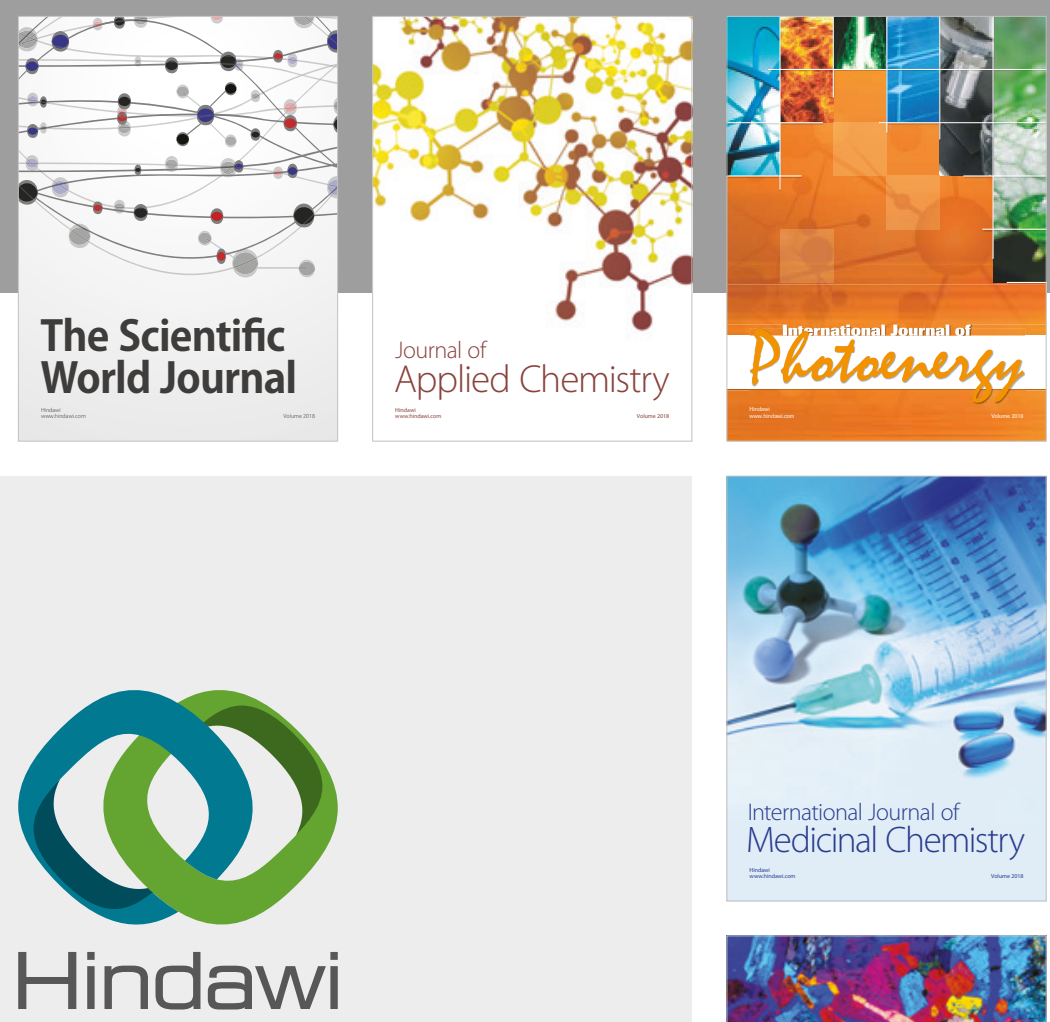

Submit your manuscripts at

www.hindawi.com
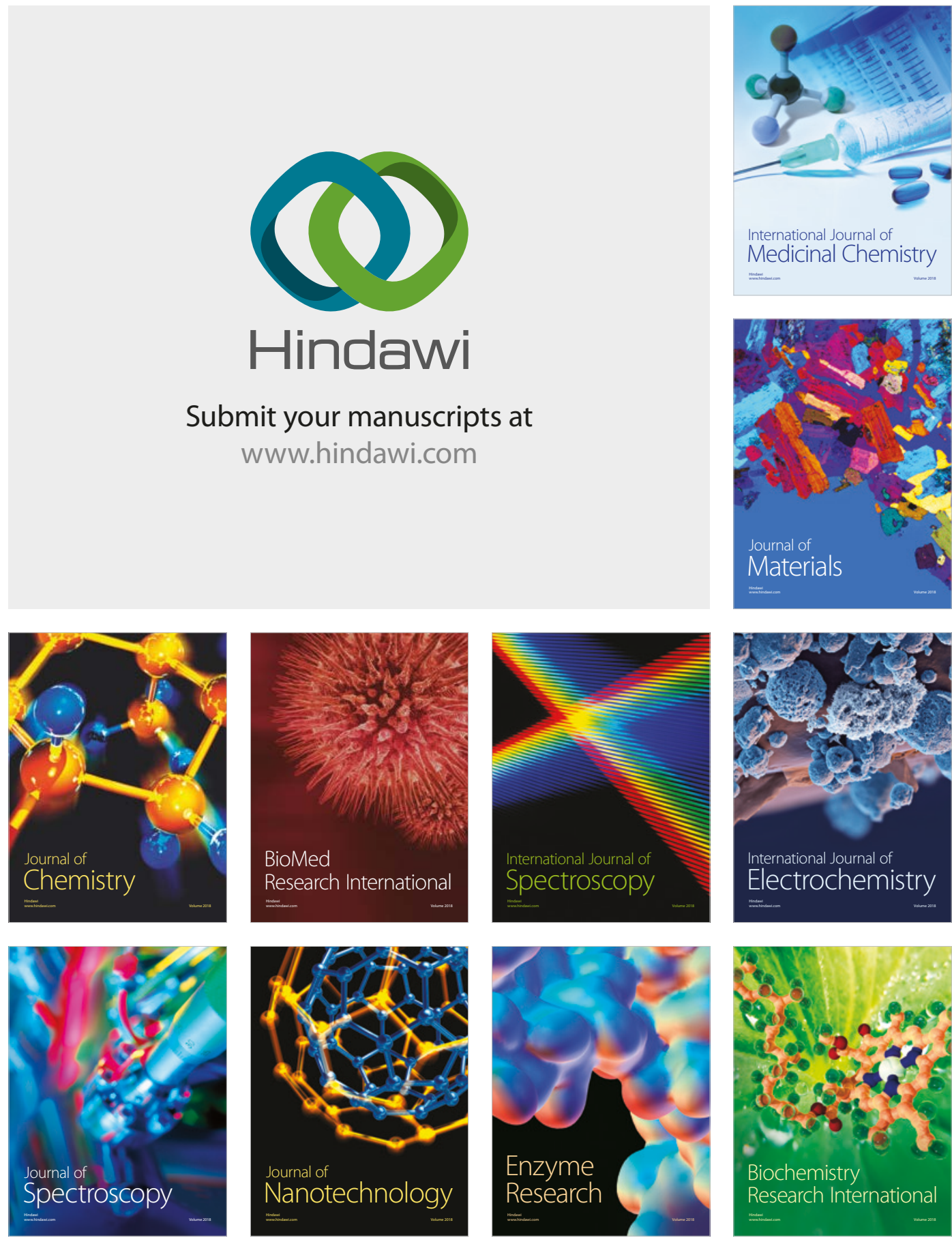
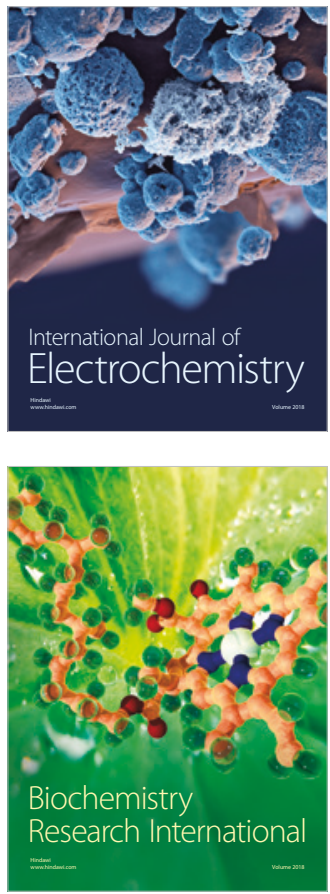